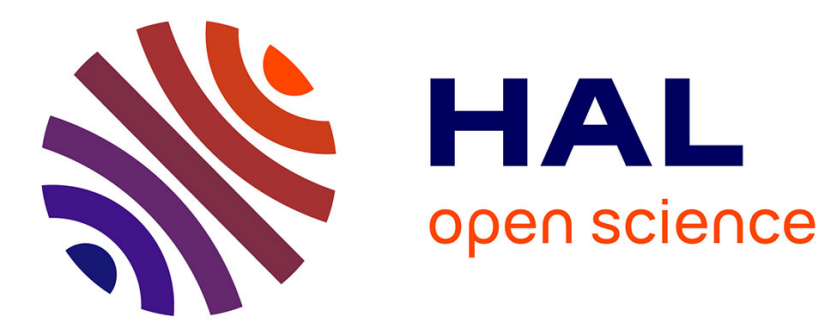

\title{
Non-fundamental Information and Market-makers' Behavior during the NASDAQ Preopening Session
}

Laurence Lescourret

\section{To cite this version:}

Laurence Lescourret. Non-fundamental Information and Market-makers' Behavior during the NAS-

DAQ Preopening Session. 2012, pp.42. hal-00772798

\section{HAL Id: hal-00772798 \\ https://essec.hal.science/hal-00772798}

Submitted on 11 Jan 2013

HAL is a multi-disciplinary open access archive for the deposit and dissemination of scientific research documents, whether they are published or not. The documents may come from teaching and research institutions in France or abroad, or from public or private research centers.
L'archive ouverte pluridisciplinaire HAL, est destinée au dépôt et à la diffusion de documents scientifiques de niveau recherche, publiés ou non, émanant des établissements d'enseignement et de recherche français ou étrangers, des laboratoires publics ou privés. 


\title{
Non-fundamental Information and Market-makers' Behavior during the NASDAQ Preopening Session
}

\author{
Research Center \\ ESSEC Working Paper 1212
}

2012

Laurence Lescourret 


\title{
Non-Fundamental Information and Market-Makers' Behavior during the NASDAQ Preopening Session ${ }^{1}$
}

\author{
Laurence Lescourret \\ ESSEC Business School 2
}

This Version: December 2012

\footnotetext{
${ }^{1}$ I thank Thierry Foucault, José Miguel Gaspar and Sophie Moinas for helpful comments and suggestions. Laurence is research fellow at CREST. Laurence gratefully acknowledges Imperial College for a visiting position in 2011 and the French National Research Agency (ANR) for its financial support (ANR-10-JCJC-1810-01). The usual disclaimer applies.

${ }^{2}$ ESSEC Business School, Avenue Bernard Hirsch, 95021 Cergy-Pontoise, France. E-mail address: lescourret@essec.edu. Phone: +33 1344333 62. Fax: +33134 433212.
} 


\begin{abstract}
This paper examines whether NASDAQ dealers' preopening quotes might be related to non-fundamental information, that is, information about transient trading pressure unrelated to fundamentals. Preopening quotes posted by wholesalers (dealers specialized in market-making and thus presumably more exposed to inventory risks) are strongly related to opening price reversals, a measure of transitory price pressure. Wholesalers are more likely to post preopening quotes on days characterized by large liquidity shocks or days following larger order imbalances, but not on days of strong informational asymmetry about fundamentals (days of analyst recommendation releases, earnings announcements or merger announcements). These patterns do not hold for other intermediaries, namely institutional brokers providing sell-side coverage. I also find that daily order imbalances (another trading pressure measure) are strongly related to the preopening activity of wholesalers but not to any other groups of market-makers with more diversified banking activities. Overall, I interpret this as evidence that non-fundamental information matters during the preopening session and impacts intermediaries' preopening behavior.
\end{abstract}

JEL Classification numbers: G12, G14, D82

Keywords: Market Microstructure, Preopen, NASDAQ, Non-fundamental Information, Price Reversals, Order Imbalances 


\section{Introduction}

Non-fundamental information concerns transitory effects on prices resulting from temporary order imbalances unrelated to asset fundamentals. That information might have common-value components related to the market trading environment (for instance, a liquidity shock due to a distressed trader) and specific private-value components related to participants (e.g., inventory adjustments, speed of trading, etc.) ${ }^{1}$ Non-fundamental information is valuable during trading hours, especially in markets operated by risk-averse market-makers in which inventory concerns are more exacerbated.

I examine the impact of non-fundamental information on intermediaries' behavior using the NASDAQ preopening before 1997. In an important contribution, Cao, Ghysels and Hatheway (2000) find that NASDAQ dealers signal information related to fundamentals during preopening to ease price discovery at the open. My paper aims at complementing their findings by focusing on non-fundamental information. I argue that dealers may find desirable to signal information not necessarily about fundamentals, but also about order imbalances or inventory shocks. I therefore ask the following questions:

- Do NASDAQ market-makers use nonbinding preopening quotes to signal transient non-fundamental information to the market?

- Are opening trading pressures related to dealers' preopening quoting behavior ?

I use this setting for several reasons. First, the NASDAQ in 1996 was operated as a nonanonymous dealer market, in which transient order imbalances might have been relevant for risk-averse dealers holding sub-optimal positions. ${ }^{2}$ Second, before 1997 NASDAQ dealers had the obligation to absorb incoming orders, either because they posted the best price, or because they received orders from affiliated brokers which they had guaranteed to

\footnotetext{
${ }^{1}$ That information is also designated as "non-payoff relevant" (Barclay, Hendershott and Kotz, 2006) or as "inventory" information (Cao et al, 2006).

${ }^{2}$ Only risk-averse liquidity providers will be concerned by potential losses due to possible adverse price movements. Note also that competition for anonymous limit order traders was introduced later with the order-handling rule of 1997, which required the inclusion of limit orders posted on Electronic Communication Networks (ECNs) in the calculation of the best market prices (National Best Bid and Offer).
} 
execute (a practice referred to as preferencing agreements) $]^{3}$ The opening was especially risky due to overnight information accumulation and the required guarantee to fill orders at the opening price. Trading during preopening hours was in practice not feasible due to prohibitive transaction costs $4^{4}$ Building a position minimizing inventory exposure at the open through trading could only be achieved at a very expensive cost. Third, recent papers find that even if the usage of non-anonymity on NASDAQ is now optional when dealers post their quotes, it is still frequently used, consistent with the hypothesis of information disclosure through dealers' identity to less informed market participants (e.g., Benhami, 2007 or Karam, 2012). Using the unique available non-anonymous NASDAQ preopening dataset is thus relevant for exploring whether any group of intermediaries finds optimal to reveal liquidity-related information.

The empirical approach consists of investigating the impact of dealers' nonbinding quotes on measures of trading pressure at the open such as price reversals or order imbalances. In particular, I focus on the behavior of wholesalers a group of very large dealers specialized mainly in market-making during the period in question. Wholesalers don't provide sell-side research coverage from which they could obtain fundamental information (e.g., Schultz, 2003 ; Madureira and Underwood, 2008). They mainly handle retail order flow during the period of the analysis (Griffin, Harris and Topaloglu, 2003), which consists of mostly uninformed trades susceptible to waives of investors sentiments (DeLong, Shleifer, Summers, and Waldmann, 1990). Moreover, wholesalers do not possess brokerage arms and therefore have to pay outside brokers to get access to order flow. Preferencing practices are profitable, but also risky in terms of inventory exposure (Kandel and Marx, 1999). For reputational reasons, wholesalers might be forced to execute orders at the best price, at any time and especially at the open, for their affiliated brokers. If the opening price reflects their order imbalance, execution risk is lowered for market-makers, especially when they commit to match the best opening price.

I therefore use wholesalers to test the hypothesis that market-makers use non-anonymous indicative quotes to communicate transient non-fundamental information. In particular,

\footnotetext{
${ }^{3}$ Preferencing and one of its various forms, internalization, refer to practices that allow brokers and institutional investors to have prearranged transactions with a preferenced dealer (a quote-matcher), avoiding search costs of the best price.

${ }^{4}$ Trading costs were more than four times larger in the preopen than during the trading day: 9.1 cents during the trading day versus 38.7 cents in the preopen in 2000 (Barclay and Hendershott, 2004).
} 
I posit that non-binding preopening quotes that cause crossed and locked inside quotes (the highest bid is greater or equal to the lowest ask across all trading venues, i.e. the best prices that create the inside spread, is crossed or locked) act as a signal to move the opening price in the desired direction. This pressure on prices is later reversed as order imbalances are accommodated by market-makers and prices move back towards fundamentals. The preopen dataset contains data on 213 NASDAQ market-makers for 50 stocks during 12 months. Despite the quasi-absence of trading (less than $0.5 \%$ of the daily trading volume), the preopen is very active in terms of nonbinding quotes (46 quotes per day on average). Crosses and locks are less frequent (1.25 on average) but caused purposely by market-makers. In particular, I observe a wide heterogeneity in market-makers' crossing and locking activity during the preopening.

I highlight three important results of the analysis. First, despite their small number (twelve in this sample), the group of wholesalers cause as many crossed and locked quotes as the most active group consisting of institutional brokers. The magnitude of price reversals increases in the frequency of signalling quotes posted by wholesalers. The preopening activity of other market-makers is not significantly related to these price pressure measures. These results indicate that transient trading pressure is related to dealers' motives to post nonbinding quotes during the preopen. It also suggests that wholesalers are more concerned by such transient price movement than any other groups of NASDAQ market-makers.

Second, wholesalers are more likely to post signalling preopening quotes on days incurring large informationless liquidity shocks (such as days of expiration of option contracts), or following days characterized by large daily order imbalances. They are however less likely to post signalling quotes on days characterized by strong informational asymmetry (takeover announcements, earnings announcements, and analyst recommendation releases) or for stocks with high institutional ownership. Other market-makers react very differently. Institutional brokers are more active during the preopen on days with large expected liquidity shocks and on days with fundamental shocks, and for stocks with high institutional ownership. In contrast, they are less likely to post quotes after days characterized by large order imbalances. The remaining categories of market-makers are not significantly influenced by any special days or by any stock characteristics. 
As a robustness check, I use the level of absolute order imbalance recorded during the first fifteen minutes of trading and for the day (Chordia, Roll and Subrahmanyam, 2002) as an alternative measure of trading pressure. Wholesalers are the only group of NASDAQ dealers whose preopening activity predicts strongly the order imbalances for the first fifteen minute and those for the day. The preopening behavior of any other groups of market-makers are not significantly related to any daily order imbalance measures.

My paper contributes to the literature on non-fundamental information. In asymmetric information models based on Kyle (1985), private information on liquidity-motivated demand allows speculators to better infer the value of fundamentals (e.g., Fishman and Longstaff 1992 ; Madrigal, 1996), to trade on their own account and front-run their clients (Röell, 1990), to profit from this information by selling it (Cheynel and Levine, 2010), or to barter it against fundamental information (Foucault and Lescourret, 2003). Cao et al (2006) build a model in which risk-averse dealers exploit their non-fundamental information to speculate before it is reflected into prices. Empirical investigations of non-fundamental information are more scarce. Cao et al (2006) find large price effects from non-fundamental information in foreign exchange markets. Barclay et al (2006) find that dealers in the U.S. Treasury market turn away from electronic brokers and prefer voice brokers when they face large order imbalances or when securities become illiquid by going off the run. Human intermediaries provide their clients the "market color" (i.e. non-fundamental information), a service difficult to replicate by fully automatized trading systems.

My paper is also related to a strand of the literature that investigates the impact of liquidity needs when markets open. On the NASDAQ, Ciccotello and Hatheway (2000) and Barclay and Hendershott (2008) find that opening prices are noisy and inefficient before 1997, which supports the view that NASDAQ opening prices incorporate information unrelated to fundamentals at the time of my study. Recently, Pagano, Peng and Schwartz (2012) show that transitory price inefficiencies at the opening of NASDAQ have been reduced with the introduction of the NASDAQ Opening Cross in 2004, consistent with the hypothesis that an auction might be an effective tool for dealers to better manage their inventories. Temporary price effects due to a transient insufficient liquidity supply at the open (and the related compensation required by traders who provide extra liquidity) have 
been documented for other exchanges $5^{5}$ The role of liquidity provision when markets open is thus a hotly debated question. My paper shows that the revelation of non-fundamental information is a way for dealers to better manage their inventory exposure.

The remainder of the paper is organized as follows. Section 2 presents a brief overview of the NASDAQ market organization and lays out the main testable hypothesis. Section 3 describes the construction of the main variables of interest and provides summary statistics. Section 4 reports the main regression results. Section 5 looks at the determinants of cross / lock activity. Section 6 provides additional evidence on the relation between trading pressures and the preopening activity of market-makers. A discussion of the paper concludes the paper.

\section{Main Hypothesis and Institutional Context}

\subsection{The NASDAQ preopening}

Today, the NASDAQ market is a quote-driven market, which operates an electronic limit order book that utilizes the INET architecture. ${ }^{6}$ Market-makers can enter quotes in the NASDAQ book under their identity, or anonymously (using the MPID of 'NSDQ'). During the period I study (Oct. 1995-Sept. 1996), the NASDAQ was a complete non-anonymous fragmented dealer market. Dealers' quotes were the only source of liquidity. In practice, NASDAQ dealers were competing to attract order flows, either through public quotes or through preferencing arrangements. $60 \%-80 \%$ of NASDAQ order flow was estimated to be preferenced before decimalization in 2001.7

Each morning before the open, dealers were able but not obliged to display their quotes in the NASDAQ quotation reporting system that was activated around 8:00 am. Prices were not anonymous and only indicative, i.e. they were nonbinding unlike firm

\footnotetext{
${ }^{5}$ See, among others, Stoll and Whaley (1990) and Madhavan and Panchapagesan (2000) for NYSE specialist data; Davies (2003) for the Toronto Stock Exchange; Ellul, Shin and Tonks (2005) for the London Stock Exchange; Kalay and Wohl (2009) for the Tel Aviv Stock Exchange and Hoffmann and van Bommel (2011) for Euronext Paris and Xetra data.

${ }^{6}$ INET (previously known as Island) was formerly a successful ECN, purchased by NASDAQ in 2005.

${ }^{7}$ Similar characteristics were observed in some other fragmented equity markets, such as the London Stock Exchange (see, e.g., Hansh, Naik and Viswanathan, 1999).
} 
prices posted during mandatory trading hours (from 9:30 am to 4:00 pm). Preopening quotes thus did not have to be honored for any minimum or posted quantity. $\left.\right|^{8}$ Despite the absence of any obligation to post quotes, and very few volume of transactions (on average, less than $0.5 \%$ of the total daily trading volume, and less than $0.25 \%$ of the total daily number of trades), the preopening period was very active, as illustrated by the amount of preopening quotes in my sample (on average $10.25 \%$ of the daily total number of inside quotes occurred during the preopening session, going up to a maximum of 84\%).9

Following this preopening period, mandatory trading hours started at 9:30 am without any formal mechanism for price discovery. The NASDAQ opening was a complete decentralized process until the implementation of an electronic call auction, referred as the "Opening Cross" in April 2004 (and completed in December of that year). The literature suggests that to overcome the absence of a formal opening process market-makers searched for equilibrium prices during the 90-minutes preopening session. The possibility to post non-anonymous nonbinding quotes enabled them to signal their willingness to trade. Cao et al (2000) argue that market-makers communicated with each other in an attempt to incorporate fundamental information into opening price to avoid the adverse selection problem created by the trading with informed traders. Interestingly, similar features of communication through nonbinding quotes are also found in other high periods of uncertainty, such as during NASDAQ trading halts (Christie, Corwin, and Harris, 2002), or before trading opens in NASDAQ IPOs (Aggarwal and Conroy, 2000).

Among nonbinding quotes, crossed and locked inside quotes have been found to convey credible information. They have been thus perceived as the main signalling device (see Cao et al, 2000, or Aggarwal and Conroy, 2000). Crossed or locked inside quotes were not authorized during trading hours, but still existed 10 My paper investigates whether dealers did post quotes that generated crossed and locked markets in order to signal

\footnotetext{
${ }^{8}$ The minimum quantity that dealers had to display during trading hours was 1,000 shares for stocks in sample at the time of my analysis.

${ }^{9}$ As established by Barclay and Hendershott (2008), I use trades marked in TAQ with a "T" designator to determine the trading volume and the number of trades executed during the preopen from Oct. 1995 to Sept. 1996.

${ }^{10}$ During my sample period, the very large majority of market participants posted quotes in the single trading platform (NASDAQ Quote Montage). Most of locks and crosses were thus purposely signal of interest. As pointed down by Shkilko et al (2008), the nature of crosses and locks has significantly changed with the implementation of Supermontage in 2002. Many ECNs decided to operate independently and posted their quotes on regional exchanges. Due to the proliferation of unlinked systems, crosses and locks now occur because of connectivity problems across systems, or of different latency across systems.
} 
non-fundamental information about transient order imbalances.

\subsection{Hypothesis Development}

In the 1990s the fragmented structure of NASDAQ lead to the proliferation of preferencing agreements. This practice was a way for brokers to avoid search costs of the best price, and for dealers to bypass price competition by securing prearranged order flow. Preferencing was however not riskless for dealers. Because the latter committed to execute preferenced orders by matching the best price, they partly lost control over their own inventory positions (Kandel and Marx, 1999; Lescourret and Robert, 2011). This risk was strengthened at the open due to the considerable overnight price uncertainty and a significant amount of orders to execute (see the reverse J-shape pattern of volatility and trading volume found on the NASDAQ by Chan, Christie and Schultz, 1995 or Barclay and Hendershott, 2008) 11

This paper builds on the hypothesis that dealers with limited risk-bearing capacity tried to manage the trading pressures at the open by using non-anonymous non-trading signals rather than expensive trading. In particular dealers might have used crossed and locked quotes to signal the direction in which the opening price should move to reflect the cost of providing liquidity at this critical period.

Empirically, I test whether there exists a relation between measures of trading pressure (price reversals and order imbalances) observed at the open and the signalling behavior of dealers during the prior preopening hours. Signals related to fundamental information should favor price discovery and their incorporation into price should lead to a price continuation. In contrast, transient non-fundamental information is supposed to have the opposite effect and lead to price reversals. If dealers, in particular wholesalers, communicate transient non-fundamental information, I expect that price reversals are negatively related to their preopening quoting activity.

Why would dealers communicate transient non-payoff relevant information?

The NASDAQ preopen I analyze was a non-anonymous, repeated game with non-

\footnotetext{
${ }^{11}$ Knight, a wholesale dealer using heavily preferencing contracts, asserted in 1999 that it lost money almost every morning because of its guarantee to fill orders at the best opening price (Ip, 2000).
} 
binding quotes. These features have several important implications. First, pre-trade communication is potentially profitable (e.g., Crawford, 1998). Using a call auction model with private valuations, Chakraborty, Pagano and Schwartz (2012) show that non-binding interactions may favor quantity discovery by letting large traders reveal their trading needs. Second, repeated non-anonymous interaction makes rivals less likely to engage in squeezes or predatory pricing due to the threat of punishment by their peers (see, e.g. Carlin, Sousa Lobo, and Viswanathan, 2007). Finally, Dia and Pouget (2005) argue that risk-averse insiders may choose to reveal unilaterally their liquidity needs and/or their fundamental information during a preplay round in order to lower the cost of liquidity (a mechanism similar to sunshine trading analyzed by Admati and Pfleiderer, 1991). They stress that information transmission is credible only if preopening is a repeated nonanonymous game. My paper indirectly tests these theoretical findings by investigating whether NASDAQ dealers may find desirable to communicate transient non-fundamental information during repeated preopening rounds.

Why would wholesalers constitute the group which is the more likely to signal nonfundamental information?

Dealers constitute an heterogenous group. The NASDAQ Economic Research departement classifies NASDAQ dealers as wholesalers, institutional brokers, wirehouses, major regional dealers and other smaller dealer firms ${ }^{12}$ During the period of the analysis, wholesalers (e.g., Knight) are specialized in market-making (they often make markets in excess of 7,000 stocks). They do not underwrite stocks or do not have brokerage operations. Thus, wholesalers largely use preferencing arrangements to get order flows which constitute the main source of their income. In particular, they pay a rebate to brokers (e.g., TD Ameritrade) to get the right to execute order flow (usually designated by "payment for order flow") 13 In contrast, institutional brokers (e.g., Goldman Sachs and Co) have retail brokerage forces. Their client base primarily consists of large institutions. They tend to be associated with underwriters. Integrated national firms, often referred to as wirehouses (e.g., Merrill Lynch) have also large retail brokerage forces. Thus, an integrated firm itself

\footnotetext{
${ }^{12}$ This classification system is standard in the literature (e.g., Huang, 2002; Schultz, 2003; Griffin et al, 2003; Tuttle, 2006; Madureira and Underwood, 2008; Anand et al, 2011). Quotes from ECNs start to intervene in the NASDAQ quote montage in 1997 with the implementation of the Order-Handling Rules.

${ }^{13}$ In 2010, these payments vary, but are typically a tenth of a cent per share (Pisani, 2010). At the time of my study, the payment was as high as $\$ 0.25$ per share.
} 
generates substantial order flow, which is executed by the market making division of the firm. The other dealer firms are divided into big regional dealers and other minor firms, depending on the number of employees, number of domestic offices, or customer accounts.

I posit that among these groups, wholesalers are the most likely to communicate nonfundamental information through their preopening behavior. First, due to a more intensive use of preferencing agreements, to their presence in a very high number of (liquid and less liquid) stocks, and to their under-diversified business, wholesalers face larger inventory risks compared to other groups. Second, wholesalers are considered less informed about fundamentals relative to the other dealers because they don't provide any research coverage: ${ }^{14}$ and they are reputed (along with regional firms) to mainly attract individual retail order flow, while institutional brokers and wirehouses predominantly handle institutional orders (Griffin et al, 2003; Anand et al, 2011). Third, it has been shown that wholesalers' quotes contains information on short-term market movements possibly due to transient trading pressures (Huang, 2002).

This paper argues that wholesalers have predominantly access to transient non-fundamental information and have more incentives to reveal it during preopening rounds. I therefore test whether price reversals are negatively related to their preopening quoting activity.

\section{Data and Summary Statistics}

\subsection{Forming the Sample}

My primary data source is the Bridge Information System 15 It contains the ticker symbol, date, time and all preopening quotes (from 8:00 a.m. to 9:30 a.m.) of a sample of 52 NASDAQ stocks from October 1, 1995 through September 30, 1996 (252 trading days) 16 The dataset includes all market-makers identifications ('MPID's) and consists of (i) the

\footnotetext{
${ }^{14}$ Market-makers with sell-side research coverage tend to be more active in the liquidity provision and the price discovery process (Madureira and Underwood, 2008), to post aggressive quotes in anticipation of changes in stock recommendations by analysts from the same market-maker firm (Heidle and Li, 2005), or to tip some of their institutional clients prior to the release of analysts' reports (Irvine, Lipson and Puckett, 2007).

${ }^{15}$ I warmly thank Frank Hatheway for kindly providing a copy of the Bridge preopening dataset.

${ }^{16}$ These are the 52 most active over the 3,772 NASDAQ stocks, as measured by the 1994 share volume.
} 
preopening bid and ask quotes by dealer and (ii) the prevailing inside quote (defined as as the best bid and best ask among dealers). Individual dealer quote and inside quote are time-stamped to the minute and are recorded in chronological sequence within a minute. The prevailing inside quote changes when the best-quoting dealer quotes change.

For the purpose of the paper, I focus on inside quotes that are crossed or locked, and identify which dealer has caused the crossed or locked market. Once a dealer has initiated a crossed/locked market, a continuous series of crossed/locked inside quotes may be observed as long as dealers do not move enough their quotes to make the inside spreads uncrossed/unlocked. I discard any crossed/locked quotes which are not caused by any dealers and belong to a sequence $\sqrt{17}$ Based on inside quotes kept in sample, I calculate the size in number of ticks $(\$ 1 / 8)$ of crossed/locked quotes and manually checked outliers (whose size is in the 99 percentile). I discard outliers arising from errors in the reporting system (e.g., the first inside quote of the preopening of the day has a best ask or a best bid unrelated to the level of the stock price), or from human errors (e.g., dealers post quotes unrelated to the current stock price, but modify them in the following minutes) 18

In addition, I collect information on closing stock prices, stock splits, market capitalization, shares outstanding and trading volume from the CRSP database over the same period.19 I use TAQ to obtain intraday bid, ask prices and trade data for the stocks in my sample.20 I gather additional data for each stock from various sources, as follows: (a) recommendations and date of earning announcements from Thomson First Call ; (b) announcement date of M\&A from SDC Platinum ; and (c) percentage ownership of institutions from Thomson Reuters Spectrum 13F filings. ${ }^{21}$ As an additional check, I match daily trading volume for the stocks computed using TAQ with the CRSP trading volume

\footnotetext{
${ }^{17}$ I discard inside crossed/locked quote whose (i) prevailing ask price is higher than or equal to the previous best ask and (ii) whose prevailing bid price is smaller than or equal to the previous best bid

${ }^{18}$ Less than $1 \%$ of crossed/locked quotes are removed.

${ }^{19}$ Ten splits impact my sample.

${ }^{20}$ TAQ provides two files: trades and inside quotes. TAQ quotes are anonymous, and time-stamped to the nearest second. I omit quotes with non-positive depth, quotes for which either the ask or bid price is non-positive, and quotes for which TAQ's MODE codes 4, 7, 9, 11, 13, 14, 15, 19, 20, 27, and 28. For trades, I drop trades coded as involving an error or a correction (TAQ's CORR field is greater or equal to 2). I also eliminate trades with nonpositive price and trades for which TAQ's COND is equal to "A", "Z", "T", "G", "W", "J" and "K". Similar filters have also been used in Bessembinder (1999).

${ }^{21}$ Data on the SEC mandated 13-F statement are only available on quarterly reporting dates. Institutional investors must fill this report if they have a long equity positions greater than 10,000 shares or $\$ 200,000$ in market value.
} 
file.

I drop two firms (Reuters and Ericy) trading as ADRs and whose underlying stock is listed in the UK ${ }^{22}$ The final sample contains 50 actively traded stocks (e.g., Apple, Cisco, Dell, Intel or Microsoft), or roughly 9,500 stock-day observations.

\subsection{Measures of Dealer Preopening Quoting Behavior}

I construct two measures of dealers' quoting behavior denoted generically by $Q B_{-} j$, for $j=\mathrm{WH}$ (wholesalers), IB (institutional brokers), WI (wirehouses), REG (big regional dealers) and OTH (other minor firms)). To obtain the first measure, I count the number of crossed and locked inside spreads initiated by each dealer group $j$ in stock $s$ on day $t$ $\left(N B R_{-} C L_{-} j_{s, t}\right)$. I standardize this number by the total number of quotes posted by that category $j\left(N B R_{-} Q U O T E S_{-} j_{s, t}\right)$ to obtain the proportion of crossed and locked quotes initiated by group $j\left(P C T_{-} C L_{-} Q U O T E S_{-} j_{s, t}=Q B_{-} j^{1}\right)$. The second measure uses the number of days on which group $j$ initiates a crossed or a locked market at least once during the preopen $\left(A C T I V E_{-} D A Y S_{-} P R E O P E N_{-} j_{s}\right)$. I standardize this measure by the number of trading days in that stock to obtain the proportion of crossed and locked quotes initiated by group $j\left(P C T_{-} C L_{-} D A Y S_{-} j_{s, t}=Q B_{-} j^{2}\right)$. Note that the first measure is available on a daily basis, whereas the second measure is only available across time.

\subsection{Measures of Overnight Price Pressure}

Price pressure effects are manifested in return or price reversals (e.g., Stoll and Whaley, 1990; Madhavan, 2001). I examine two measures of reversals. The first measure is the Pearson correlation coefficient of returns. For stock $s$, for the signed close $(c)$ to open $(o)$ log return and signed open $(o)$ to time ' $i$ ' log return, the linear correlation coefficient is expressed as follows:

$$
R E V_{-}{ }^{\prime} i_{s}=\operatorname{Corr}\left(\log \left(P_{s}^{o} / P_{s}^{c-1}\right), \log \left(P_{s}^{i} / P_{s}^{o}\right)\right),
$$

\footnotetext{
${ }^{22}$ Markets between ADRs and the underlying stocks are not completely integrated (Werner and Kleidon, 1996), and information flows may affect the preopening of ADRs very differently from local common stocks, resulting in atypical quoting behaviors of market-makers. Note that the two previous studies using the same dataset (Cao et al, 2000 and Ciccotello and Hatheway, 2000) include these two ADRs.
} 
where $P_{s}^{o}\left(P_{s}^{c-1}\right)$ is the midpoint of the minimum ask quote and maximum bid quote at the opening (resp. at the previous close) for stock $s$, and $i=10 \mathrm{AM}, 1030 \mathrm{AM}$ and 11AM. I use the interval between 10:00 am and 11:00 am following Ciccotello and Hatheway (2000) (who use 11:00 am to compute opening price reversals) and Barclay et al (2008) (who use 10:00 am). Using midquotes ensures that my results are not due to bid-ask bounce.

I also use the measure of price pressure defined in Bao, Pan and Wang (2008):

$$
\operatorname{AUTOCOV}_{-} i^{\prime}{ }_{s}=\operatorname{Cov}\left(\Delta\left(P_{s}^{o}-P_{s}^{c-1}\right) ; \Delta\left(P_{s}^{i}-P_{s}^{o}\right)\right)
$$

I remind that a negative return autocorrelation or a negative autocovariance of price changes indicates a temporary price deviation at the opening, which results from the incorporation of non-fundamentals factors. A price continuation is observed when prices incorporate fundamental information over subsequent periods.

To reduce the importance of outliers, I winsorize the sample at $1 \%$ and $99 \%$ percentiles when calculating price reversal measures.

\subsection{Liquidity Shock Days}

Following the literature (Barclay et al, 2008; Cushing and Madhavan, 2000) I need to control for days on which liquidity shocks at the open occur. These shocks are unrelated to changes in the fundamental value of stocks. Still, the dealers in the market must absorb them, creating transitory price reversals. In addition, dealers might be willing to participate more actively to the preopening around these days for inventory control reasons.

I use the option expiration dates (each third Friday of the month) as a proxy for days in which liquidity stocks are expected to arise. Among these Fridays, expiration days for the S\&P500 futures contract are worth to mentioning. They are often referred to as "witching days" or "freaky Friday" since they are triple expiration days: S\&P500 contracts for stock index futures, stock index options and stock option all expire on that same third Friday of every March, June, September, and December. These triple expirations generate exogenous, large liquidity shocks at the open, and occasionally an increase in volatility of 
prices of related securities (Barclay et al, 2008). I thus add a dummy variable denoted $d_{-} L S$ to control for these days with expected liquidity shocks. ${ }^{23}$

I also control for days on which a fundamental shock $(F S)$ occurs. I define a fundamental shock as a change in fundamental value that can affect prices permanently. I use days around specific market events usually associated with fundamental information release: mergers and acquisitions announcements, earnings announcement date, and analyst recommendation releases. The variable $d_{-} F S$ is a dummy that takes 1 for days incurring such fundamental shocks.

\subsection{Summary Statistics}

\subsubsection{Firm Variables}

Table 1 provides summary statistics for the 50 stocks in the sample. Panel A summarizes stock-level measures. Market capitalization ranges from $\$ 431$ Million to $\$ 53$ Billion, with a median of $\$ 3.4$ Billion. The average (median) daily volume of stocks in the sample is 50 (24) million dollars, and the average (median) closing price is $\$ 41$ (\$39). The first 15 minutes of trading after the open represent up to $11.5 \%$ of the daily number of trades, with a median slightly under $8 \%$. If trades were equally distributed during the day, the first 15 minutes of trading should represent 3.85\%. The latter result stresses the economic importance of the opening, and it is consistent with the reverse J-shaped pattern found in other studies.

The Pearson correlation coefficient of returns and the autocovariance of price changes. The return correlation coefficient at 11:00 am has a mean of -0.167 and ranges from -1.112 to 0.355 , while the mean for autocovariance of price change at 11:00 am is about -0.015 . Both price reversal measures present similar characteristics: they do not differ much across time horizons (10:00 am, 10:30 am or 11:00 am), but tend to increase significantly at the close of the trading session $(4: 00 \mathrm{pm})$, indicating that the level of noise declined

\footnotetext{
${ }^{23}$ I obtain qualitatively identical results when I also include days on which a stock in my sample is added or deleted from the S\&P500 index (only 7 observations in total). Stocks added or deleted from an index tend to experience peak in volume on the day prior to the index modification (the effective date of the addition/deletion), which might cause price pressure (see, e.g., Grossman and Miller, 1988 for a theoretical model and Lynch and Mendenhall, 1997 for empirical findings).
} 
significantly by the end of the trading day ${ }^{24}$

In average, across all stocks, there are 62 days (over 252 trading days) during which the market is crossed/locked at least once during the preopening with a maximum (minimum) of 205 (3) days. In comparison, the market is crossed/locked on average 28 days during the mandatory trading session. Over the period, the number of preopening quotes ranges from 1,831 to 30,280 , with a median of 9,193. The number of crossed/locked markets is much less frequent with a median of 146, ranging from 6 to 1,324. On a daily basis, the average (median) stock registers 46 (37) quotes and 1.25 (0.65) crossed/locked inside quotes. The average preopening represents, in median, $8 \%$ of the daily number of inside quotes, ranging from $3.7 \%$ to almost $30 \%$.

\subsubsection{Dealer Group Variables}

Table 1, Panel B reports that there are 213 different market-makers in sample with the following breakdown: 12 wholesalers, 18 institutional brokers (among whom some are also classified as top analysts by Institutional Investors in 1996), 12 wirehouses (4 are classified top analysts), 10 big regional dealer firms and 162 other minor firms ${ }^{25}$ Panel B shows that wholesalers and wirehouses post preopening quotes in 42 over 50 stocks in median (within their respective group), institutional brokers in 33.5, big regional dealers in 24 and others in 2 stocks. These statistics correspond to the description of the classification reported above: wholesalers post quotes in more stocks and have a potential larger exposition to inventory shocks. Wirehouses also post quotes in a large number of stocks, but their activities are more diversified. They are thus less dependent on the market-making business.

Panel C reports statistics concerning market-makers' preopening behavior by categories. With a median of almost 9 daily preopening quotes, wholesalers post less preopening quotes than institutional brokers do (the p-value of a Wilcoxon difference of medians test is $<.003$ ), but more than the other groups (p-value <.001) ${ }^{26}$ Wholesalers

\footnotetext{
${ }^{24}$ Unreported t-tests confirm that the price reversal measures at the close of the trading day are statistically and significantly different than those computed at each of the three morning time intervals used.

${ }^{25}$ I thank Paul Schultz for kindly sharing the list of wholesalers used in Schultz (2003).

${ }^{26} \mathrm{I}$ investigate median values because the distributions of variables described in Panel $\mathrm{C}$ are skewed.
} 
initiate as many crossed/locked markets as institutional brokers do ( $\mathrm{p}$-value $=.8$ ), and much more than any other groups $(\mathrm{p}$-value $<.001)$. In percentage of their own preopening quotes, wholesalers cause slightly more crossed/locked quotes than institutional brokers (0.90 versus $0.76, \mathrm{p}$-value $=.06)$. Both wholesalers and institutional brokers are the most active groups over the period during the preopen ( $\mathrm{p}$-value $<0.001$ for each difference of medians with the other groups). Wholesalers have therefore an economically significant activity during preopening, at least as much as institutional brokers, which includes the most influential market-makers in terms of price discovery like Morgan Stanley or Goldman Sachs (Cao et al, 2000).

\section{Results}

\subsection{Cross-Section Examination}

This subsection presents evidence concerning my hypothesis by looking at the average relation between price reversal around the open and the quoting behavior of marketmakers during the preopen. I estimate the following White-adjusted ordinary least-squares (OLS) cross-sectional regression for the opening price reversals:

$$
Y_{-}{ }^{6} i_{s}^{\prime}=\alpha+\sum_{j} \beta_{j} \overline{Q B}_{-} j_{s}+\gamma \mathbf{X}_{\mathbf{s}}+\varepsilon_{s}
$$

where the dependent variable $Y$ is one of the two measures of price reversal $\left(R E V_{-}{ }^{6} i{ }^{\prime}\right.$ or $\left.\mathrm{AUTOCOV}_{-} \cdot i^{\prime}\right)$ and $\overline{Q B}$ is the independent variable reporting the cross/lock activity of dealers during the preopen, for $i=10 \mathrm{AM}, 1030 \mathrm{AM}$ and 11AM and for $j=\mathrm{WH}$, IB, WI, REG, and OTH. Also included is $\mathbf{X}_{\mathbf{s}}$, a matrix containing the following control variables: the average (log) daily dollar trading volume, the average daily return standard deviation, the average (log) market capitalization, the average daily total number of preopening quotes $\left(N B R_{-} Q U O T E S\right)$, and the number of trading days during which at least one crossed or a locked market was recorded during the preopen (ACTIVE_DAYS_PREOPEN).

Table 2 presents OLS estimates of the regression model. Panel A and B report results related to the first and second price pressure measures, respectively. Each column shows 
the results obtained for each trading time (10:00 am, 10:30 am and 11:00 am). I report two specifications: the first uses the percentage of crossed and locked quotes initiated by group $j\left({\overline{Q B} j_{s}}_{s}^{1}={\overline{P C T \_} C L_{-} Q U O T E S_{-}}_{j_{s}}\right)$ and the second uses the percentage of days on which group $j$ causes at least one crossed/locked market during the preopening $\left.\overline{Q B_{-} j_{s}^{2}}=P C T_{-} C L_{-} D A Y S_{-} j_{s}\right)$.

The most important result from Table 2 is that the impact of the quoting behavior of wholesalers is negative and significant, indicating that stocks with more crossing or locking wholesalers exhibit higher price reversal. Across all 6 measures of price reversal and all specifications, wholesalers are the only group to get a systematic and statistically significant expected sign on price pressure at the open. None of the other groups are consistently significant across all measures and/or specifications. This result provides preliminary but strong evidence in support of the hypothesis that wholesalers use preopening crossed/locked signals to indicate transient non-fundamental information.

\subsection{Daily Analysis}

To investigate further the relation between the preopening quoting behavior of dealers and non-fundamental information during preopening hours, this section explores price pressure at the daily level, which allows to control for specific days, in particular days on which there are large, informationless, predictable liquidity shocks.

\subsubsection{Multivariate Analysis}

From Barclay et al (2008), I define the price reversal for stock $s$ on day $t$ as the product of the return from the previous close to the open $o$ and the return from the open $o$ to time $i$, where $i=10 \mathrm{AM}, 1030 \mathrm{AM}$ and 11AM. I run the following regression:

$$
\begin{aligned}
R E V_{-} \cdot i_{s, t}^{\prime}= & \alpha+\sum_{j} \beta_{j} Q B_{-} j_{s, t}+\gamma_{1} \times d_{-} L S_{s, t}+\gamma_{2} \times d_{-} F S_{s, t} \\
& +\gamma_{3} \times \mathbf{X}_{\mathbf{s}, \mathbf{t}}+\gamma_{4} \times N B R_{-} Q U O T E S_{s, t}+\varepsilon_{s, t} .
\end{aligned}
$$

where the independant variable $Q B$ is the variable defined above measuring the crossing or locking activity of group $j$ in stock $s$ on day $t$. I also add controls for specific days. 
Recall that the variable $d_{-} L S$ is a dummy variable that takes a value of 1 for days incurring expected liquidity shocks (560 stock-day observations), and zero otherwise. The variable $d \_F S$ is a dummy that takes 1 for days incurring fundamental shocks (811 observations in the sample).

The matrix $\mathbf{X}_{\mathbf{s}}$ controls for characteristics of the stock $s$, namely: (log) market capitalization, (log) dollar trading volume and standard deviation of daily returns. These variables are calculated for the prior calendar month and expressed as deviations from the mean (Barclay et al, 2008). I also include the (log) daily number of quotes (NBR_QUOTES) recorded during the preopening session to control for the level of preopening activity.

Table 3 provides estimates of the panel regression. Each column shows the results obtained for the price reversal measured at 10:00 am, at 10:30 am and at 11:00 am. I report three specifications according to the measure of quoting behavior of group $j, Q B_{-} j$. On day $t$ for stock $s$, the first measure is a dummy $\left(d_{-} j\right)$ that takes the value of 1 if group $j$ causes at least one crossed or locked market. The second measure is the percentage of crossed or locked inside quotes initiated by group $j, P C T_{-} C L_{-} Q U O T E S_{-} j$, which is defined above. The third measure is the (log) number of crosses or locks initiated by group $j, N B R_{-} C L_{-} j(j=\mathrm{WH}, \mathrm{IB}, \mathrm{WI}, \mathrm{REG}$ and $\mathrm{OTH})$. I include day fixed effects (Petersen, 2009), and use Rogers (clustered) standard errors throughout my analysis.

The main result from Table 3 confirms the statistically significant effect of crosses and locks initiated by wholesalers on price reversals. Across all measures of price reversals (10:00 am, 10:30 am or 11:00 am), the price reversal is stronger if the crossing/locking activity of wholesalers is higher. This relation holds no matter how this activity is measured, though PCT_CL_QUOTES has the weakest relation to reversals. In terms of economic impact, Column 1 indicates that price reversals at 10:00 am are stronger by $11.6 \%$ when wholesalers cross or lock the market at least once (this represents about $50 \%$ of the unreported average price reversal, which is -0.22 in the panel sample). Estimates in Columns 2 and 3 imply that a one-standard deviation shock in PCT_CL_QUOTES_WH (resp. NBR_CL_WH) increase reversals by about $20 \%$ (resp. 34\%) also relative to the average $[27$ It is worth noticing that none of other groups' activity has a systematic impact

\footnotetext{
${ }^{27}$ The standard deviations of the variables $P C T_{-} C L_{-} Q U O T E S_{-} W H$ and $N B R_{-} C L_{-} W H$ are 4.5 and 0.47 , respectively.
} 
on price reversals.

Results for control variables indicate that price reversals are stronger on days characterized by liquidity shocks, but only for reversals before 10:00 am. The total number of quotes during the preopening session is positively related to price reversals, which means that strong quoting activity is correlated with weak price reversals or even price continuations. Remaining control variables do not seem to have any significant explanatory power. In summary, my results are consistent with the hypothesis that market-makers, in particular wholesalers, cause crossed or locked inside quotes around days characterized by higher price reversals related to temporary trading pressure.

\section{Liquidity Shocks and Impact on Dealers' Preopen- ing Behavior}

My main hypothesis assumes that market-makers may behave differently during the preopen due to a different degree of exposition to inventory risk (wholesalers vs. other groups) and to heterogeneity of access to information flows. A dealer's decision whether to cross or lock the inside spread on day $t$ may depend on day-specific liquidity shocks, fundamental shocks, or other stock-specific factors. I thus look at the following logistic regression:

$$
\begin{aligned}
\operatorname{Pr}\left(d_{-} j\right)= & \alpha+\beta_{1} d_{-} L S_{s, t}+\beta_{2} O I M B_{-} D A Y_{s, t-1}+\beta_{3} d_{-} F S_{s, t}+\beta_{4} F R C I O_{s, t} \\
& +\beta_{5} \mathbf{X}_{s, t}+\beta_{6} N B R_{-} Q U O T E S_{s, t}+\varepsilon_{s, t}
\end{aligned}
$$

where $d_{-} j$ is the dummy variable that takes 1 if group $j$ crosses or locks the market during the preopen on day $t$ in stock $s$. The independent variables of interest are the dummy variable $\left(d_{-} L S\right)$ which is set to 1 for days incurring expected liquidity shocks and the daily order imbalance of the previous trading day $\left(O I M B_{-} D A Y_{s, t-1}\right)$. I also include variables controlling for fundamental information access: the dummy variable, $d_{-} F S$, that takes the value 1 for days characterized by fundamental information release (earnings announcement date, analyst recommendation releases, mergers and acquisitions announcements) and the fraction of institutional ownership (FRCIO). I use the fraction 
of institutional ownership as a proxy for the fraction of informed order flow and therefore as control for the degree of adverse selection in a stock (see Sarin, Shastri and Shastri, 1999; Agarwal, 2007). This variable is also related to dealers. Institutional brokers have most likely institutional clients and thus work large institutional orders, while wholesalers are reputed to be reluctant to provide liquidity to orders from program trading or institutional clients. I expect that unlike institutional brokers, wholesalers should be less prone to execute order flows in stocks with more institutional ownership ${ }^{28}$ The remaining control variables (X and $N B R_{-} Q U O T E S$ ) are as detailed in the previous sections.

The maximum likelihood estimates of the coefficients from the logistic regressions, along with their standard errors are reported in Table 4. Each column reports the results for each group of dealers (wholesalers, institutional brokers, wirehouses, major regional firms, and other small firms). Interestingly, groups react in an heterogeneous way.

The likelihood that wholesalers cross or lock the market significantly increases on days of informationless liquidity shocks and on days following larger daily order imbalances. Calculation of the marginal effects indicate that the increase is $5.8 \%$, or about one third of the unconditional likelihood $(17.40 \%)$ shown in Table 1. Days in which fundamental shocks occur have no influence. Simultaneously, the probability to cross or lock the market is lower for stocks with larger institutional ownership, as expected. Wholesalers are thus more likely to cross/lock the market on days associated with liquidity shocks or days following larger order imbalances, but not on days of strong informational asymmetry about fundamentals (days of analyst recommendation releases, earnings announcements or merger announcements).

Institutional brokers post crosses/locks on both days with fundamental information release and days of expected liquidity shocks. Unlike wholesalers, the probability that institutional brokers cross or lock the market is higher for stocks with larger institutional ownership. This result suggests that institutional brokers might be induced to cross/lock the market to signal both fundamental and non-fundamental information.

Results with respect to other groups show that the decision to lock or cross the market for wirehouses doesn't seem to be influenced by any special days affected by liquidity or fundamental shocks. Wirehouses are slightly more likely to cross or lock the market for

\footnotetext{
${ }^{28}$ Data related to FRCIO are missing for 3 over 50 stocks in sample in Spectrum 13F filings.
} 
stocks with higher institutional ownership. Big regional dealers' behavior do not seem to be impacted by any variables of interest. "Other" minor firms are less likely to cause a crossed or a locked market during preopening sessions following days with larger order imbalances. Other variables have no impact on their decision.

In summary, these results are consistent with the central hypothesis that NASDAQ wholesalers are more exposed to inventory risk and use crossed/locked markets to signal transient non-fundamental information.

\section{6. $\quad$ Order Flow Imbalances}

Another angle to analyze the relation between trading pressure and preopening activity is thus to study whether crosses/locks predict order imbalances at the open.

My main hypothesis is based on the inventory paradigm, that postulates that dealers are intermediaries accommodating buying and selling needs from the buy-side investors. Large order imbalances exacerbate the inventory problem faced by dealers that might struggle to re-adjust their inventory position once they precommit to accommodate trading pressures, as it might be the case for preferencing arrangements. Order imbalance is the signed volume that measures direction and degree of buying or selling pressure, and is a proxy for excessive trading interest. Order imbalances are strongly associated to price changes in intermediated markets (Ho and Stoll, 1983 ; Chordia et al, 2002).

I posit that, in case of anticipated order imbalances at the open, it might be worth for dealers to indicate which direction price should move to alleviate inventory concerns. I should thus observe a positive relation between the preopening quoting activity of dealers and order imbalances. This effect could even be stronger for wholesalers that are likely to be forced to execute orders preferenced to them, and thus potentially more exposed to order imbalances.29

\footnotetext{
${ }^{29}$ The determinants of order imbalances are still empirically unclear. Order imbalances might result either from the trading activity of informed speculators (e.g., Kyle, 1985) or from that of uninformed traders hit by liquidity shocks (e.g., Andrade, Chang and Seasholes, 2008). Empirically, Kim and Stoll (2010) fail to find any significant relation between order imbalances and informed trading. In any case, handling large order imbalances aggravates the exposure of dealers to inventory risk and, in the worst situation, might also result in adverse execution.
} 
I use the order imbalance measure defined in Chordia et al (2002), which consists of the number of buyer-initiated trades less the seller-initiated trades for each stock and each day. The direction of trades is designated using the Lee and Ready (1991). Specifically, in order to sign trades I compare the trade price to the midpoint algorithm using the five-second lagged midquote as a reference price ${ }^{30}$ I then use absolute order imbalance measures (inventory imbalances resulting indifferently from buying or selling pressure) 31 Untabulated results show that the average (median) level of absolute order imbalances is 29 (15) trades for the first 15 minutes and 193 (96) trades for the day.

I run two regression models. The first regression model (Model I) explores the crosssectional relation between order imbalances and crossed/locked markets caused by dealers.

$$
\overline{O I M B_{-}^{\cdot} i^{\prime}}{ }_{s}=\alpha+\sum_{j} \beta_{j} \overline{Q B_{-}} j_{s}+\gamma \mathbf{X}_{\mathbf{s}}+\varepsilon_{s}
$$

where the left-hand side variable $\overline{O I M B_{-}{ }^{\prime} i} i^{\prime}$ is the average daily order imbalance in number of trades of stock $s$ during the first 15 minutes of the trading session $\left(\overline{O I M B \_15}\right)$ and for the day $\left(\overline{O I M B \_D A Y}\right)$ across the sample period. The explanatory variable $\overline{Q B}$ and the matrix of control variables $\mathbf{X}$ are as detailed in Section 4.1 .

The second regression model (Model II) estimates the relation at the daily level between order imbalances and the preopening quoting activity of dealers.

$$
\begin{aligned}
O I M B_{-}{ }^{\prime} i_{s, t}^{\prime}= & \alpha+\sum_{j} \beta_{j} Q B_{-} j_{s, t}+\gamma_{1} \times d_{-} L S_{s, t}+\gamma_{2} \times d_{-} F S_{s, t}+\gamma_{3} \times O I M B_{-} D A Y_{s, t-1} \\
& +\gamma_{4} \times \mathbf{X}_{\mathbf{s}, \mathbf{t}}+\gamma_{5} \times N B R_{-} Q U O T E S_{s, t}+\varepsilon_{s, t} .
\end{aligned}
$$

where the dependent variable is the daily trade imbalance recorded during the first 15 minutes of trading $(i=15)$ and for the day $(i=\mathrm{DAY}) . Q B, d_{-} L S, d_{-} F S$, the matrix of control variables $\mathbf{X}$ and $N B R_{-} Q U O T E S$ are detailed in Section 4.2.1. This model also uses the lagged daily absolute trade imbalance as a control variable for two reasons: First, opening order imbalances could result from trading pressures that carry over from the previous close to the following opening; Second, adding lagged order imbalances controls

\footnotetext{
${ }^{30}$ Using TAQ, I aggregate all trades that execute at the same price during the same second for each stock and keep the last quote if there are several quotes within the same second.

${ }^{31}$ Using signed measures of order imbalance produces qualitatively similar results.
} 
for persistence in this variable (Chordia et al, 2002).

Table 5 reports OLS estimates of Model I. Order imbalances at the open or during the day are strongly positively correlated with the crossing/locking activity of wholesalers for all measures of quoting behavior. In contrast, order imbalances are negatively related to the preopening activity of institutional brokers. I do not find a systematic and statistically significant relation for any of the other dealer groups. Results for the control variables indicate that order imbalances are positively related to proxies for the level of preopening activity (coefficients of $N B R_{-} Q U O T E S$ and $A C T I V E \_D A Y S_{-} P R E O P E N$ statistically significant at $10 \%$ or better in all specifications) and to the the market capitalization (but only for $\overline{O I M B \_15}$ ). The other control variables are not significantly related to the dependent variables.

Table 6 presents estimates of Model II. Each column shows the results obtained for each of the dependent variables: (i) order imbalances recorded during the first 15 minutes of trading, $O I M B_{-} 15$ and (ii) order imbalances for the day, $O I M B_{-} D A Y$. I report three specifications, for each of the three independent variables measuring dealers' preopening quoting behavior. In total, there are 6 specifications.

Table 6 confirms the positive and statistically significant relation between wholesalers' preopening behavior and trading pressure measured by order imbalances. Across both time horizons of order imbalances and all quoting behavior measures, order imbalances are significantly larger when wholesalers cause more crossed or locked inside quotes (the t-statistics vary between 2.06 and 4.24). When wholesalers cross or lock the market at least once during the preopening, order imbalances observed during the first 15 minutes (resp. during the day) increase by $25 \%$ (15\%) relative to the mean, which is economically significant ${ }^{32}$ In contrast, the relation with any other groups of dealers is much weaker: only big regional dealers are significantly related to order imbalances but only for 4 specifications across 6 . None of the other groups (institutional brokers, wirehouses and others) have a consistent significant explanatory power across specifications. The overall fit of the model is good with $R^{2}$ statistics ranging from $47 \%$ to $61 \%$.

Among the control variables, as expected, the variable controlling for the lagged daily

\footnotetext{
${ }^{32}$ This corresponds to the ratio of the coefficient $d_{-} W H$ to the unreported average of the dependent variable $O I M B_{-} 15$ (resp. $\left.O I M B_{-} D A Y\right)$.
} 
order imbalance has a strong positive impact on order imbalance around the opening and that for the day. Order imbalances on days incurring fundamental shocks are significantly larger. In summary, the results are consistent with the working hypothesis.

\section{Conclusion and Discussion}

This paper uses a group of big NASDAQ dealers (wholesalers) whose main activity was market-making to test whether transient non-fundamental information might be at stake during the preopen. The period I use is unique in the sense that preopen trading was almost zero due to very large transaction costs. Liquidity providers were thus unable to build or unload inventory position to anticipate adverse moves of their inventory at the open. My hypothesis states that market-makers might be induced to use non-binding quotes as non-trading device to incorporate this non-fundamental information into opening price. By making the stock price reflect information about order imbalances, dealers lower execution risk at the open. The gains in doing so would be large for dealers that guarantee to fill orders at the opening price, like wholesalers.

The evidence is consistent with the main hypothesis. I find that: (1) the signalling activity through crosses or locks from wholesalers is strongly and significantly related to overnight price pressure measures, unlike other market-makers ; 2 ) wholesalers are the only group of dealers who are more likely to cross or lock the market on days characterized by expected liquidity shocks or following days with larger order imbalances, or for stocks characterized by a lower degree of adverse selection ; (3) wholesalers are also the only dealers whose behavior is found to be strongly related to order imbalances recorded at the open or for the day. Besides contributing to the preopening literature, this paper is the first to provide direct evidence on the relation between transient information (about price pressure or order imbalance), and the preopening behavior of market-makers.

These results are of interest for regulators because they raise the issue of the efficiency of prices at the open. If dealers signal indications of order imbalances during the preopen, opening prices contain a transitory component that reflects the price of liquidity. This transitory component might be related to oligopolistic rent extracted by NASDAQ market-makers, raising the problem of potential misbehavior from market-makers to in- 
crease their trading profits at the opening (Ciccotello and Hatheway, 2000) ${ }^{33}$ Regulators may find hard to disentable compensation for bearing extra risks during non-trading periods (Longstaff, 1995) from extraction of supplementary trading profits. Subsequently NASDAQ implemented various policy initiatives to unlock or uncross the market (e.g., the "Trade-or-Move" Rule in 2000, amended in 2002 with SuperMontage allowing automatic execution of crosses or locks) and adopted the electronic Opening Cross auction in 2004 ${ }^{34}$ A centralized disintermediated opening (like a call auction) does not however suffice to insure non manipulated opening prices (see Hauser, Kamara and Shurki, 2006 ; Biais, Bisière and Pouget, 2008).

Beyond regulatory issues raised by crosses and locks, this paper documents the importance of non-payoff relevant information for market-makers, and liquidity providers in general. This type of information is not only relevant for dealer markets whose importance has dwindled down ; it has become an important component of any electronic markets populated by high frequency traders specialized in market-making, who have replaced traditional liquidity providers. These electronic high frequency market-makers operate with very low capital, have very short holding period (few seconds), very small inventory position and seek to end the trading day in a flat position. They use the speed of trading to control inventory risk and real-time data analysis of the market environment (i.e., very short-lived non-fundamental information) to profit from future price changes. The role of non-fundamental information is thus emphasized in this environment of new marketmakers with very limited risk-bearing capacity. The May 6, 2010 Flash Crash might be an example of the challenges caused when large traders seek to buy or sell quantities larger than what market-makers are willing to hold. Irrespective of the form of market organizations, non-fundamental information is of very high interest to both researchers and market participants alike. It is a promising topic deserving future research.

\footnotetext{
${ }^{33}$ During the sample period, NASD Regulation sanctioned and fined Morgan Stanley, classified as institutional broker in the paper, for raising the price of 10 securities that underlied the Nasdaq 100 Index without trading at the open on two separate "expiration Fridays" in 1995. The tactic was used to facilitate a program trade (NASD Regulation, Press Release, April 13, 1998).

${ }^{34}$ Pagano, Peng and Schwartz (2008) find that the NASDAQ Opening Cross has sharpened the price discovery and the informational efficiency of opening prices.
} 


\section{References}

[1] Admati, A., and P. Pfleiderer, 1991. Sunshine trading and financial market equilibrium, Review of Financial Studies 4, 443-481.

[2] Agarwal, P., 2007. Institutional Ownership and Stock Liquidity, Cornell University, Working paper.

[3] Aggarwal, R., and P. Conroy, 2000. Price discovery in initial public offerings and the role of the lead underwriter, Journal of Finance 55, 1-34.

[4] Anand, A., V. Gatchev, L. Madureira, C. Pirinsky, S. Underwood, 2011. Geographic proximity and price discovery: Evidence from NASDAQ, Journal of Financial Markets 14, 193-226.

[5] Andrade, S., C. Chang, and M. Seasholes, 2008. Trading imbalances, predictable reversals, and cross-stock price pressure, Journal of Financial Economics 88, 406423.

[6] Bao, J., J. Pan, and J. Wang, 2008. Liquidity of Corporate Bonds, Unpublished working paper.

[7] Barclay, M. J., and T. Hendershott, 2004. Liquidity Externalities and Adverse Selection: Evidence from Trading After Hours, Journal of Finance 59, 681-710.

[8] Barclay, M. J., and T. Hendershott, 2008. A comparison of trading and non-trading mechanisms for price discovery, Journal of Empirical Finance 15, 839-849.

[9] Barclay, M. J., T. Hendershott, and C. M. Jones, 2008. Order consolidation, price efficiency, and extreme liquidity shocks, Journal of Financial and Quantitative Analysis 43(1), 93-122.

[10] Barclay, M. J., T. Hendershott, and K. Kotz, 2006. Automation versus intermediation: Evidence from treasuries going off the run, Journal of Finance 61, 2395-2414.

[11] Bessembinder, H., 1999. Trade Execution Costs on Nasdaq and the NYSE: A PostReform Comparison. Journal of Financial and Quantitative Analysis 34, 387-408. 
[12] Benhami, K., 2007. Liquidity providers' valuation of anonymity: The NASDAQ market evidence. University of Toulouse working paper.

[13] Biais, B., Ch. Bisière and S. Pouget, 2008. Equilibrium discovery and preopening mechanisms in an experimental market, Unpublished working paper.

[14] Cao, H. H., M. Evans, and R. K. Lyons, 2006. Inventory Information, Journal of Business 79, 325-364.

[15] Cao, C., E. Ghysels, and F. Hatheway, 2000. Price discovery without trading: evidence from the Nasdaq preopening, Journal of Finance 55, 1339-1365.

[16] Carlin, B., M. S. Lobo, and S. Viswanathan, 2007. Episodic Liquidity Crises: Cooperative and Predatory Trading. Journal of Finance 62, 2235-2274.

[17] Ciccotello, C., and F. Hatheway, 2000. Indicating ahead: best execution and the Nasdaq preopening, Journal of Financial Intermediation 9, 184-212.

[18] Chakraborty, A., M. S. Pagano, R. Schwartz, 2012. Order revelation at market openings, Journal of Financial Markets, 15, 127-150.

[19] Chan, K. C., W. G. Christie, and P. H. Schultz, 1995. Market structure and the intraday pattern of bid-ask spreads for NASDAQ securities, Journal of Business 68, 35-60.

[20] Cheynel, E., and Carolyn B. Levine, 2010. Analysts' sale and use of non-fundamental information, Review of Accounting Studies, Forthcoming.

[21] Chordia T., R. Roll and A. Subrhamanyam, 2002. Order Imbalance, Liquidity, and Market Returns, Journal of Financial Economics, 65, 111-130.

[22] Christie, W., S.A. Corwin, and J.H. Harris, 2002. Nasdaq trading halts: The impact of market mechanisms on prices, trading activity, and execution costs, Journal of Finance 57, 1443-1478.

[23] Crawford, V., 1998. A Survey of Experiments on Communication via Cheap Talk, Journal of Economic Theory 78, 286-298. 
[24] Cushing, D., and A. Madhavan, 2000. Stock returns and trading at the close Journal of Financial Markets 3(1), 45-67.

[25] Davies, R.J., 2003. The Toronto stock exchange preopening session, Journal of Financial Markets 6, 491-516.

[26] DeLong, J. B., A. Shleifer, L. H. Summers, and R.J. Waldmann, 1990. Noise Trader Risk in Financial Markets, Journal of Political Economy 98, 703-738.

[27] Dia, M., and S. Pouget, 2005. Liquidity formation and preopening periods in financial markets, CRG Working paper no. 2005-163, IAE Toulouse.

[28] Foucault, T., and L. Lescourret, 2003. Information Sharing, Liquidity and Transaction Costs in Floor-Based Trading Systems, Finance 24, 45-78.

[29] Griffin, J., J. Harris, and S. Topaloglu, 2003. The dynamics of institutional and individual trading, Journal of Finance 58, 2285-2320.

[30] Grossman, S., and M. Merton H, 1988. Liquidity and Market Structure, Journal of Finance 43, 617-37.

[31] Hansch, O., N. Y. Naik, and S. Viswanathan, 1999. Preferencing, internalization, best executions and dealer profit? Journal of Finance 54, 1799-1828.

[32] Hauser, S., A. Kamara, and I. Shurki, 2006. Pre-opening price discovery: Information or manipulation? Unpublished working paper.

[33] Heidle, H., and X. Li, 2005. Information leakage and opportunistic behavior before analyst recommendations: An analysis of the quoting behavior of Nasdaq market makers, Mimeo.

[34] Ho, T., and H. R. Stoll, 1983. The dynamics of dealer markets under competition. Journal of Finance 38, 1053-1074.

[35] Hoffman, P., and J. van Bommel, 2011. Transparency and ending times of call auctions: A comparison of Euronext and Xetra, LSF Research Working Paper Series ${ }^{\circ}$ 11-09. 
[36] Huang, R. D., 2002. The quality of ECN and Nasdaq market maker quotes, Journal of Finance 57, 1285-1319.

[37] Ip, G., 2000. Role as Big Nasdaq Market Maker Helps Knight/Trimark's Portfolio, The Wall Street Journal.

[38] Irvine P., M. Lipson, and A. Puckett, 2007. Tipping, Review of Financial Studies 20, $741-768$.

[39] Kalay A., and A. Wohl, 2009. Detecting liquidity traders, Journal of Financial and Quantitative Analysis 44, 29-54.

[40] Karam, A., 2012. The value of non-anonymity on the NASDAQ, Queen's University Belfast working paper.

[41] Kim, T., Stoll, H., 2010. Are order imbalances related to information? University of California working paper.

[42] Kyle, A., 1985. Continuous Auctions and Insider Trading, Econometrica 53, 13151335.

[43] Kandel, E., and L. M. Marx, 1999. Payment for order flow on NASDAQ. Journal of Finance 54, 35-66.

[44] Lescourret, L. and Ch. Y. Robert, 2011. Transparency matters: Price formation in the presence of order preferencing, Journal of Financial Markets 14, 227-258.

[45] Longstaff, F., 1995. How Much Can Marketability Affect Security Values? Journal of Finance 50, 1767-1774.

[46] Lynch, A., Mendenhall, R., 1997. New evidence on stock price effects associated with changes in the S\&P 500 index. Journal of Business 70, 351-383.

[47] Madhavan, A., 2001. The Russel reconstitution effect, Working Paper, ITG Inc.

[48] Madhavan, A., and V. Panchapagesan, 2000. Price discovery in auction markets: A look inside the black box, Review of Financial Studies 13, 627-658.

[49] Madrigal, V., 1996. Non-Fundamental Speculation, Journal of Finance 51, 553-578. 
[50] Madureira, L., and S. Underwood, 2008. Information, sell-side research, and marketmaking, Journal of Financial Economics 90, 105-126.

[51] Pagano, M., L. Peng, and R. Schwartz, 2008. Market structure and price formation at market openings and closings: Evidence from Nasdaq's calls, Unpublished Working Paper.

[52] Petersen, M., 2009. Estimating Standard Errors in Finance Panel Data Sets: Comparing Approaches, Review of Financial Studies 22, 435-480.

[53] Pisani, B., 2010. Man Vs. Machine: Tracing Trades Through Electronic Maze, CNBC. Available at http://www.cnbc.com/id/38974297/page/2/.

[54] Roell, A., 1990. Dual-Capacity Trading and Market Quality, Journal of Financial Intermediation 1, 105-124.

[55] Sarin, A., Shastri, K.A., and K. Shastri, 2000. Ownership structure and stock market liquidity, University of Pittsburgh Working Paper.

[56] Schultz, P. H., 2003. Who makes market? Journal of Financial Markets 6, 49-72.

[57] Shkilko, A. V., B. Van Ness, and R. Van Ness, 2008. Locked and crossed markets on NASDAQ and the NYSE, Journal of Financial Markets 11, 308-337.

[58] Stoll, H., and R. Whaley, 1990. Stock market structure and volatility, Review of Financial Studies 3, 37-71.

[59] Tuttle, Laura, 2006. Hidden Orders, Trading Costs and Information, Unpublished Working Paper.

[60] Werner I. M., and A. W. Kleidon, 1996. U.K. and U.S. Trading of British Cross-Listed Stocks: An Intraday Analysis of Market Integration, Review of Financial Studies 9 (2), 619-664. 


\section{Table 1}

\section{Summary Statistics}

This table reports summary statistics for the data used in this study. The sample consists of the 50 most traded NASDAQ stocks in the year 1994, for which all preopening quotes (from 8:00 a.m. to 9:30 a.m.) from October 1, 1995 through September 30, 1996 (252 trading days) are obtained from the Bridge Information System. These data are complemented by data from CRSP, TAQ, Thomson First Call, SDC Platinum and Thomson Reuters Spectrum 13-F filings. All statistics are calculated for the period of October 1995 to September 1996.

In Panel A, I report various aggregate trading statistics for stocks. Means are calculated yearly for each stock. A grand mean is then calculated across stocks. VOLDOL is the daily volume of trades reported in CRSP in millions of dollars. Daily return standard deviation ( $R_{-}$STDEV) is the standard deviation of the daily return reported in CRSP. Price is the daily closing price in dollars in CRSP. Market capitalization $(\mathrm{MV})$ is price times shares outstanding reported, in millions of dollars, in CRSP. $R E V_{-}{ }^{\prime} i_{s}^{\prime}$ and $\mathrm{AUTOCOV}_{-}{ }^{\prime} i_{s}^{\prime}$ are measures of price reversal, respectively calculated as follows:

$$
\begin{gathered}
R E V_{-} i_{s}^{\prime}=\operatorname{Corr}\left(\log \left(P_{s}^{o} / P_{s}^{c-1}\right), \log \left(P_{s}^{i} / P_{s}^{o}\right)\right) \text { and } \\
A U T O C O V_{-} i_{s}^{\prime}=\operatorname{Cov}\left(\Delta\left(P_{s}^{o}-P_{s}^{c-1}\right) ; \Delta\left(P_{s}^{i}-P_{s}^{o}\right)\right),
\end{gathered}
$$

where the closing (midpoint) price, $P^{c-1}$, is from CRSP, while the opening (midpoint) price, $P^{o}$ and the (midpoint) price at time ' $i$ ' $(i=10 \mathrm{AM}, 1030 \mathrm{AM}, 11 \mathrm{AM}$ or $4 \mathrm{PM})$ are from TAQ. PCT_TRADE_15 is the ratio between the number of trades recorded during the first 15 minutes of the trading session and the total number of trades reported during mandatory hours. ACTIVE_DAYS_PREOPEN is the number of days during which the market is crossed or locked at least once during the preopen (8:00 am - 9:30 am) across the period. ACTIVE_DAYS_SESSION is the number of days during which the market is crossed or locked at least once during the mandatory trading session (9:30 am - 4:00 pm) across the period. NBR_QUOTES_TOT is the total number of preopening quotes across the period, while NBR_CL_TOT is the total number of preopening crosses or locks across the period. NBR_QUOTES is the average daily number of quotes posted during the preopen across all market-makers, NBR_CL is the daily average number of times the market is crossed or locked during preopen. PCT_INSIDEQ is the daily average ratio between the number of changes in the inside quotes during the preopen over the total number of changes in the inside quotes during the trading day.

In Panel B, I report summary statistics for market-makers reported in the Bridge preopening dataset. The number of market-makers, \#, in each group results from a classification based on different sources (Huang, 2002 ; Schultz, 2003 ; the Nasdaq Research department, the 1996 Securities Industry books). Marketmakers are classified into 5 groups: Wholesalers (WH), Institutional Brokers (IB), Wirehouses (WI), Big Regional firms (REG) and other small firms (OTH). The number of stocks is the number of stocks in which market-makers quote at least once during preopening hours across the period, calculated across the group to which they belong.

Panel C shows summary statistics for the preopening activity of market-makers broken into groups, $\mathrm{j}=$ Wholesalers (WH), Institutional Brokers (IB), Wirehouses (WI), Big Regional dealers (REG) and other small dealer firms $(\mathrm{OTH})$. Each column presents statistics for a group. NBR_CL is the daily number of crosses and locks initiated by group $\mathrm{j}$ during the preopen. NBR_QUOTES is the daily number of quotes posted by group $\mathrm{j}$ during the preopen. PCT_CL_QUOTES is computed as the ratio between the daily number of crosses or locks caused by group $\bar{j}$ on the total daily number of preopening quotes posted by this group. PCT_CL_DAYS is computed as the ratio between the number of days on which group $\mathrm{j}$ causes at least one crossed or locked market during the preopen over the number of trading days across the period. 


\begin{tabular}{|c|c|c|c|c|c|}
\hline \multicolumn{6}{|c|}{ PANEL A } \\
\hline & Mean & Median & Std. Dev. & Min & Max \\
\hline MV & 6,160 & 3,402 & 10,117 & 431 & 52,773 \\
\hline VOLDOL & 50 & 24 & 79 & 1 & 452 \\
\hline Price & 41 & 39 & 22 & 7 & 104 \\
\hline R_STDEV & 0.032 & 0.033 & 0.011 & 0.015 & 0.058 \\
\hline $\mathrm{REV}_{-} 4 \mathrm{PM}$ & -0.057 & -0.055 & 0.115 & -0.266 & 0.302 \\
\hline REV_10AM & -0.166 & -0.175 & 0.351 & -1.758 & 0.564 \\
\hline REV_1030AM & -0.151 & -0.198 & 0.314 & -1.510 & 0.607 \\
\hline $\mathrm{REV}_{-} 11 \mathrm{AM}$ & -0.167 & -0.172 & 0.245 & -1.112 & 0.355 \\
\hline AUTOCOCOV_4PM & -0.006 & -0.004 & 0.046 & -0.193 & 0.134 \\
\hline AUTOCOV_10AM & -0.013 & -0.007 & 0.051 & -0.233 & 0.155 \\
\hline AUTOCOV_1030AM & -0.011 & -0.008 & 0.062 & -0.226 & 0.190 \\
\hline AUTOCOV_11AM & -0.015 & -0.009 & 0.048 & -0.184 & 0.159 \\
\hline $\mathrm{PCT}_{\mathrm{A}} \mathrm{TRADE} \_15$ & 7.98 & 7.95 & 1.26 & 4.45 & 11.31 \\
\hline ACTIVE_DAYS_PREOPEN & 62 & 38 & 56 & 3 & 205 \\
\hline ACTIVE_DAYS_SESSION & 28 & 21 & 27 & 1 & 127 \\
\hline NBR_QUOTES_TOT & 10,961 & 9,193 & 7,276 & 1,831 & 30,280 \\
\hline NBR_CL_TOT & 301 & 146 & 344 & 6 & 1324 \\
\hline NBR_QUOTES & 45.91 & 36.97 & 28.95 & 8.13 & 120.64 \\
\hline NBR_CL & 1.26 & 0.64 & 1.40 & 0.02 & 5.27 \\
\hline PCT_INSIDEQ & 10.32 & 8.14 & 6.18 & 3.67 & 29.32 \\
\hline
\end{tabular}

\begin{tabular}{|c|c|c|c|c|c|c|}
\hline \multicolumn{7}{|c|}{ PANEL B } \\
\hline \multirow[t]{2}{*}{ Groups } & \multirow[t]{2}{*}{ \# } & \multicolumn{5}{|c|}{$\begin{array}{c}\text { Number of stocks in which group } \mathrm{j} \text { quotes during the } \\
\text { preopen }\end{array}$} \\
\hline & & Mean & Median & Std. Dev. & Min & Max \\
\hline WH & 12 & 34.83 & 42 & 18 & 4 & 50 \\
\hline IB & 18 & 33.39 & 33.50 & 12 & 12 & 50 \\
\hline WI & 12 & 37.58 & 42 & 12 & 13 & 50 \\
\hline REG & 10 & 23.60 & 24 & 11 & 10 & 39 \\
\hline OTH & 161 & 3.40 & 2 & 4 & 1 & 21 \\
\hline Total & 213 & 10.58 & 3 & 15 & 1 & 50 \\
\hline
\end{tabular}




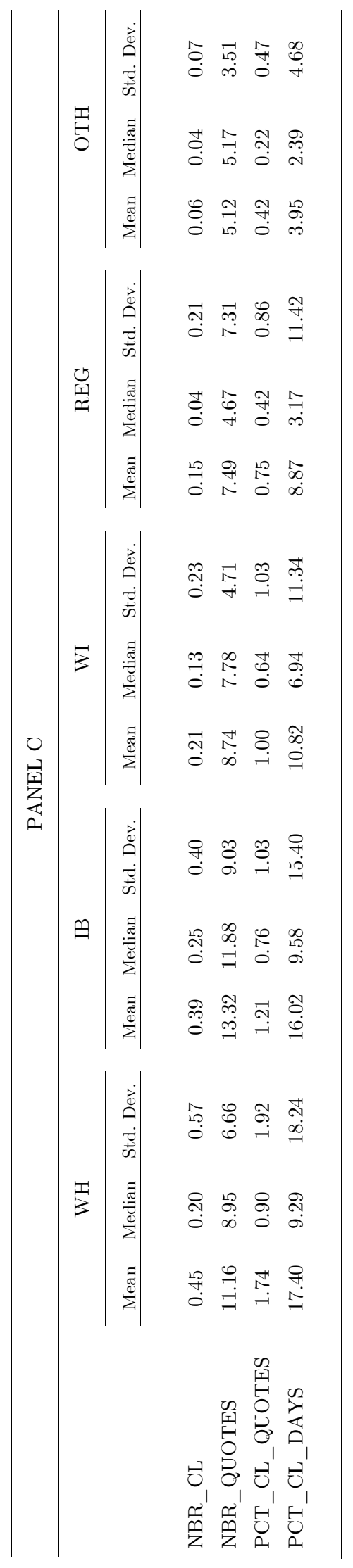




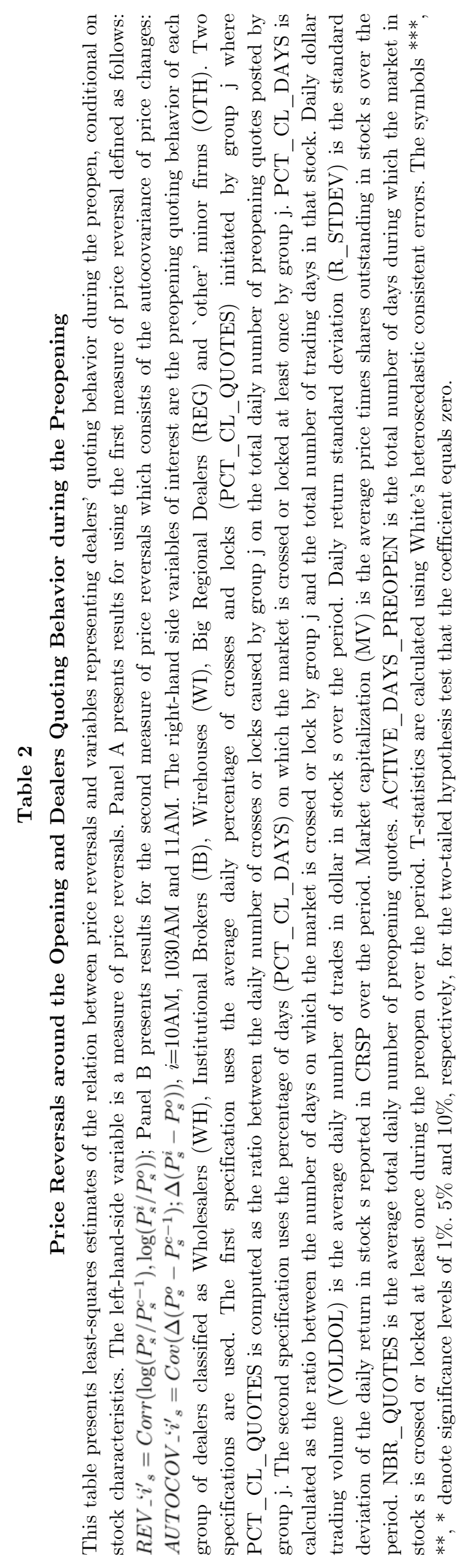




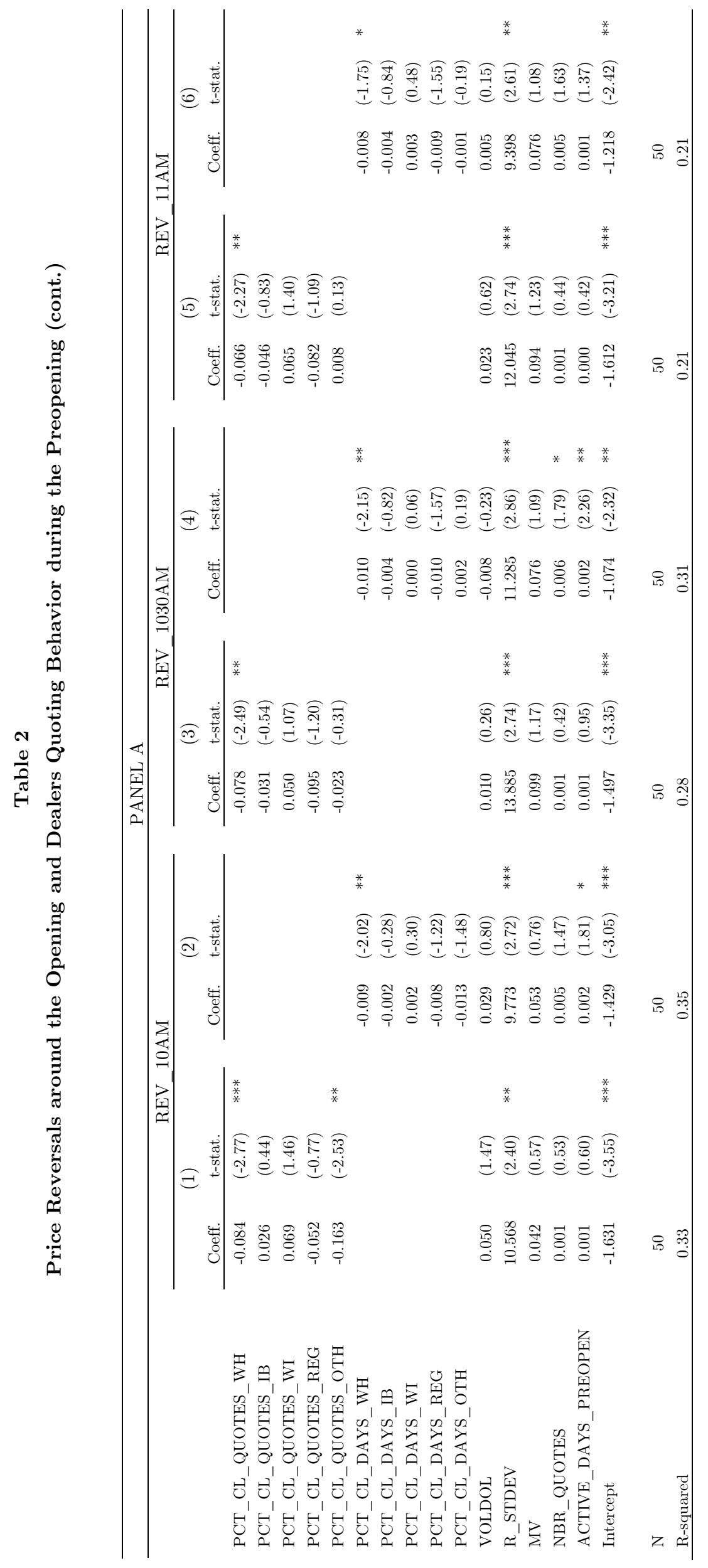




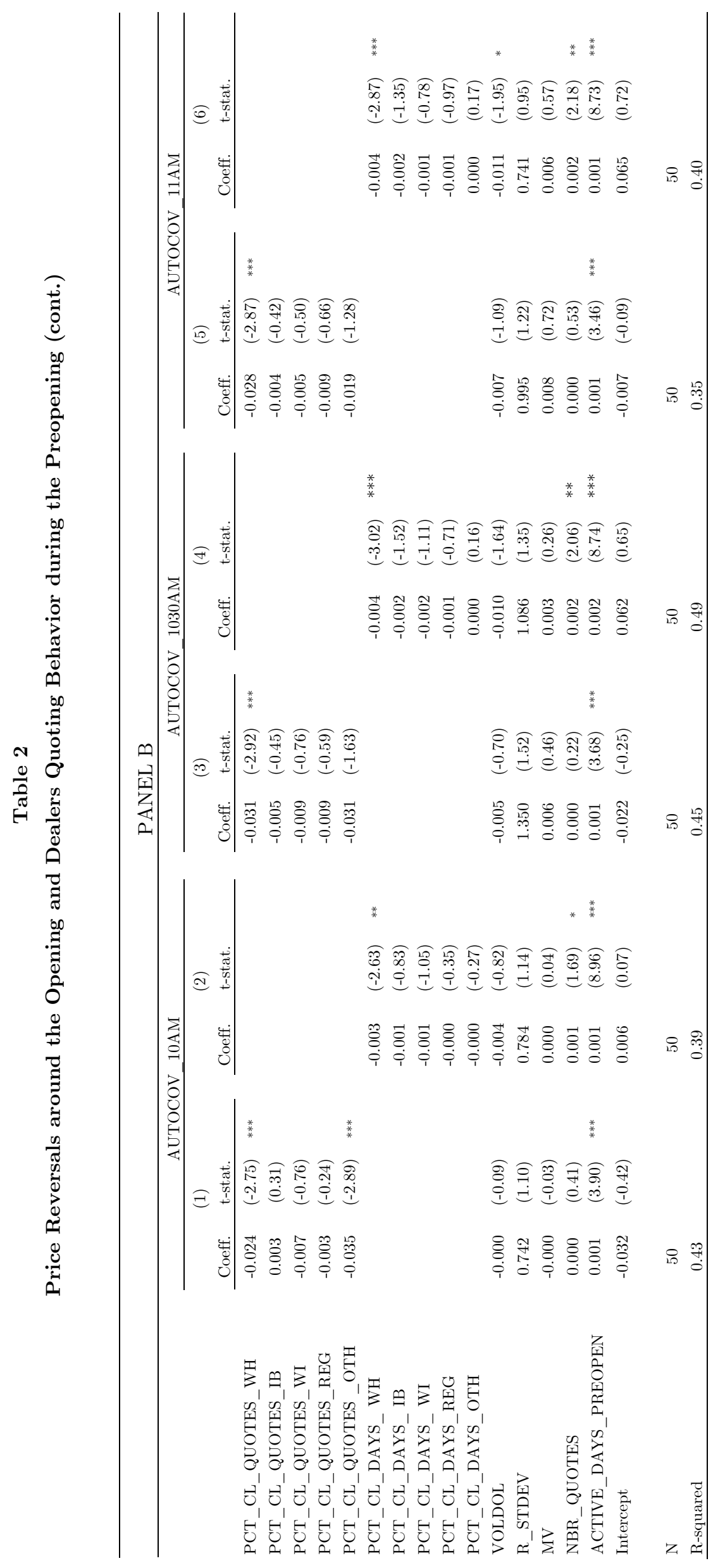




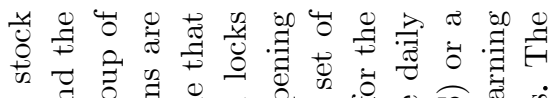

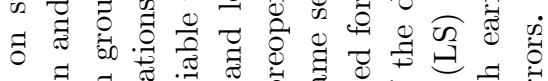

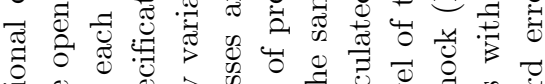

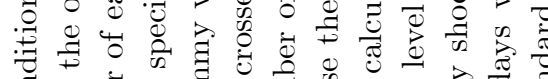

○

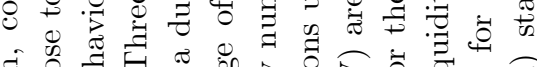

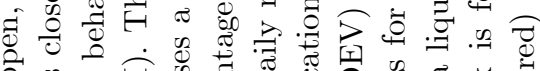

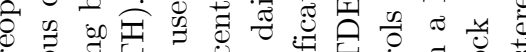

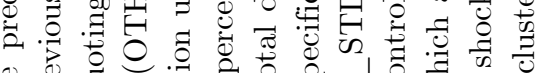

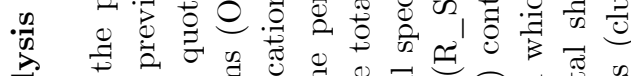

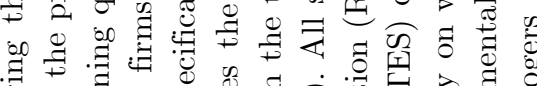

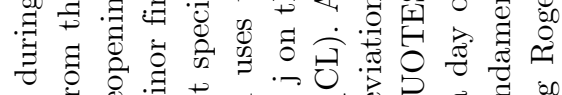

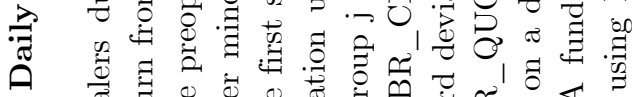

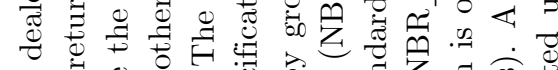

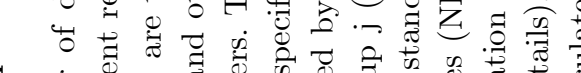

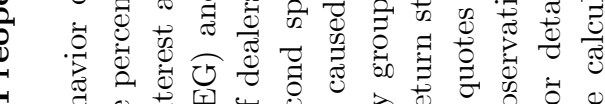

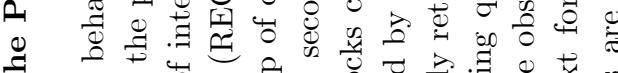

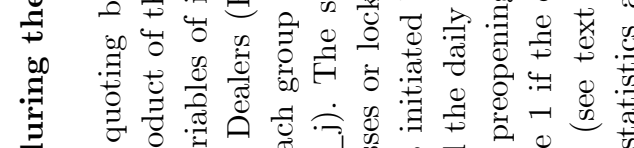

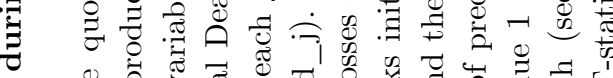

可

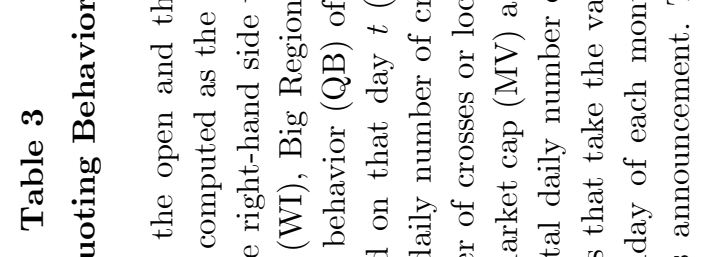

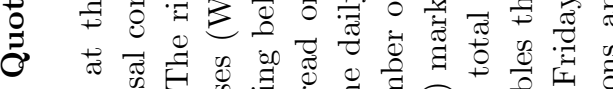

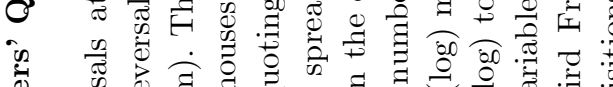

क्षे

๑ $\quad 0.0$.

สี

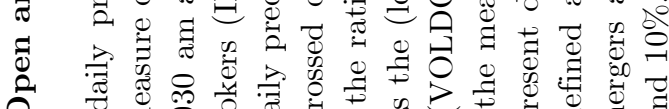

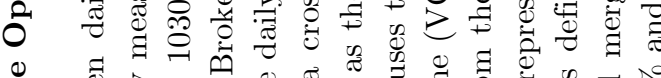

Ð

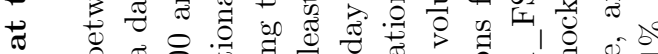

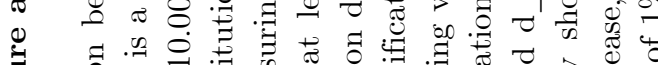

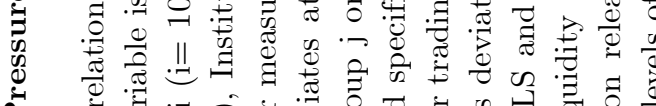

A

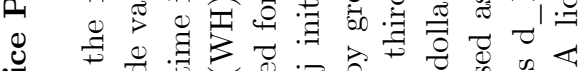

D

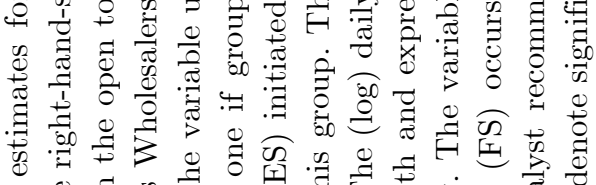

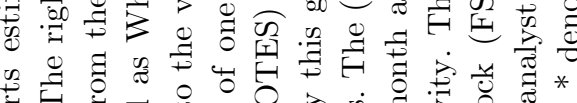

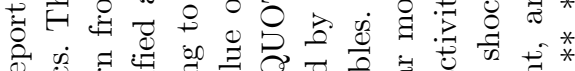

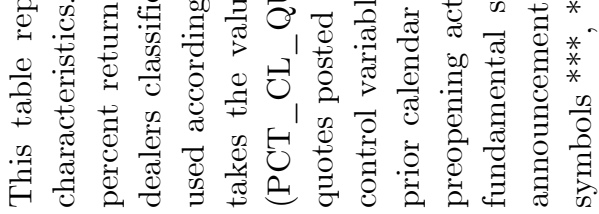




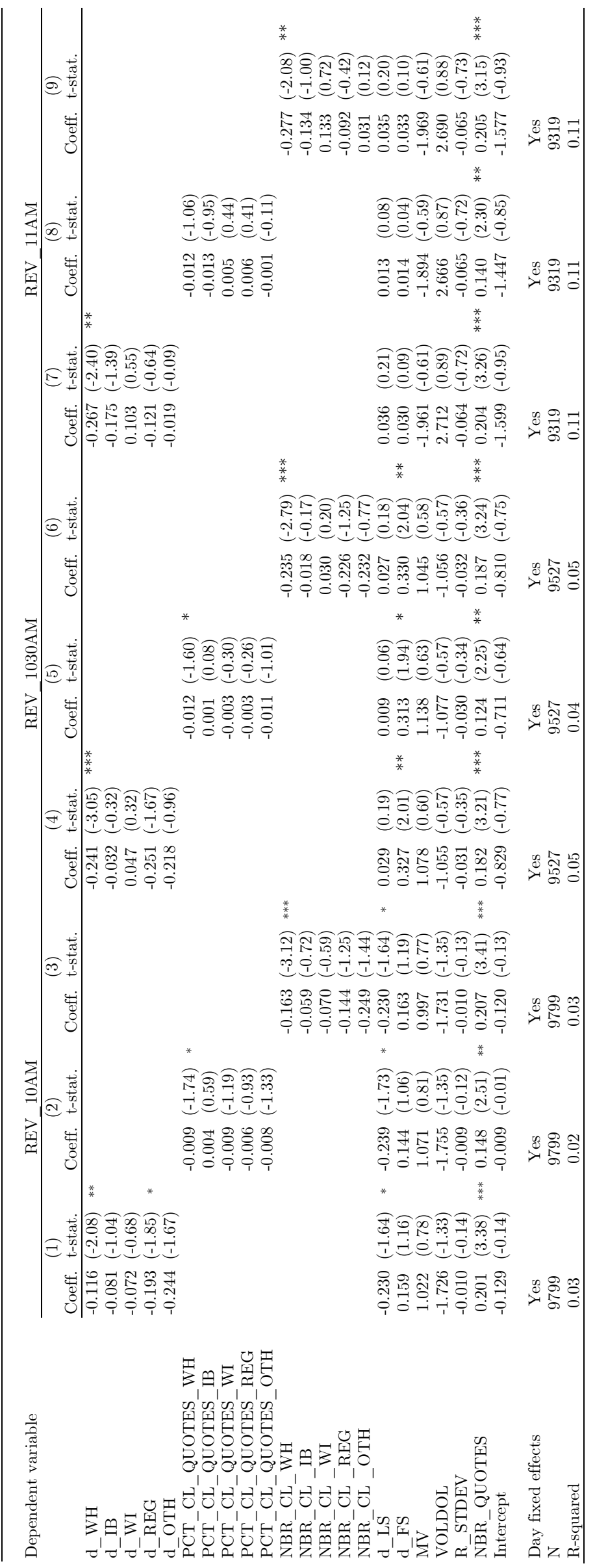




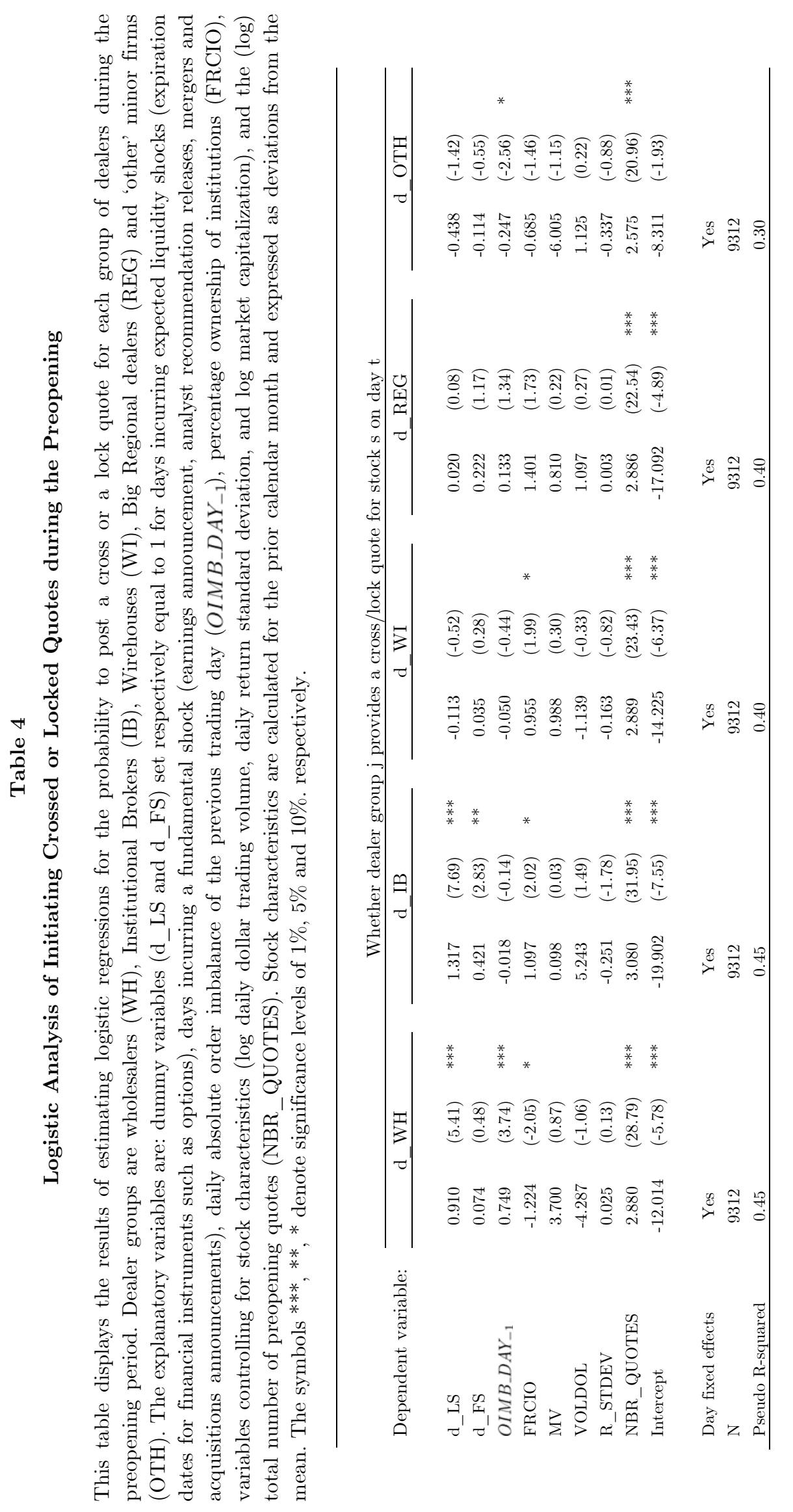




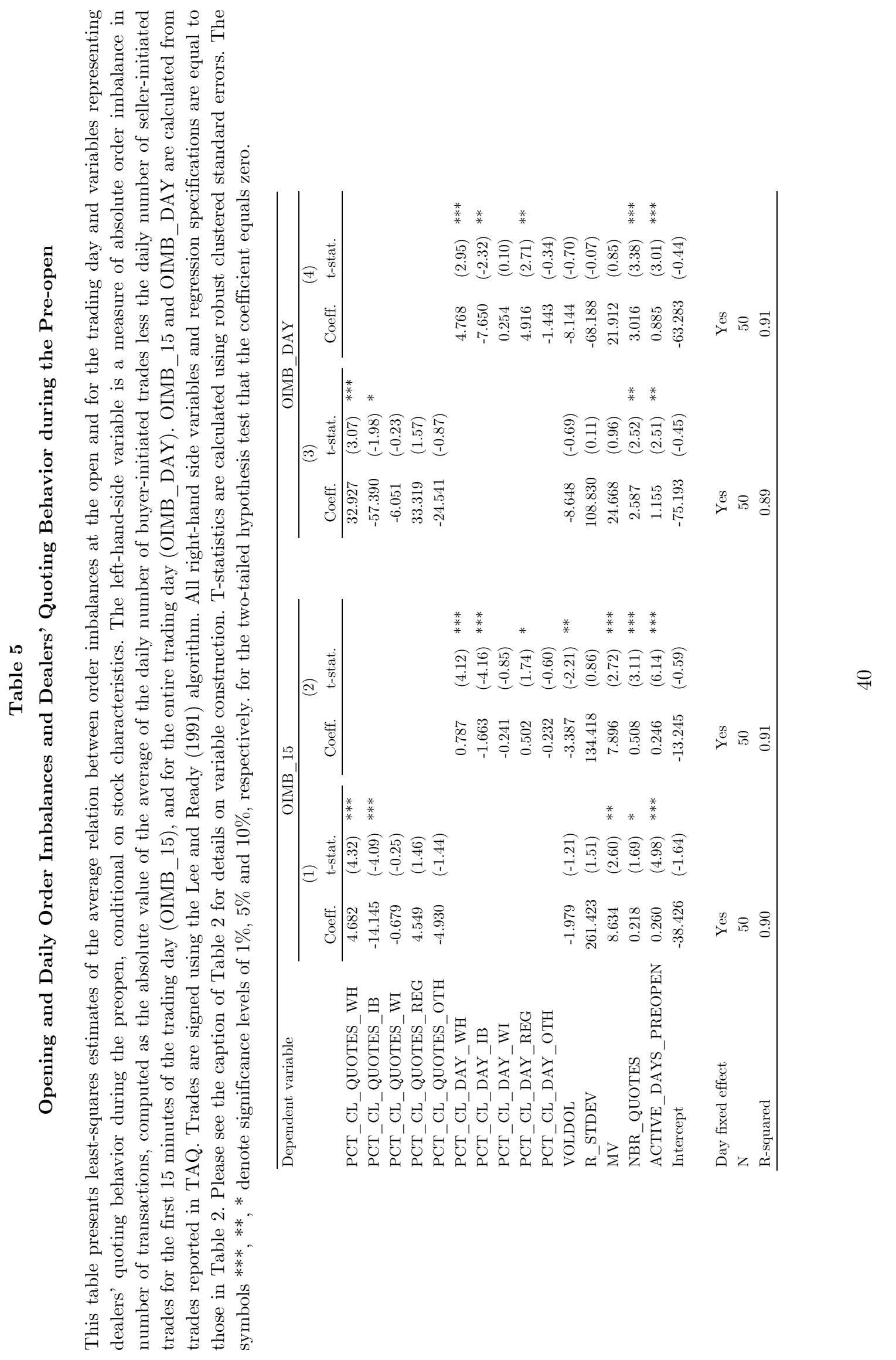



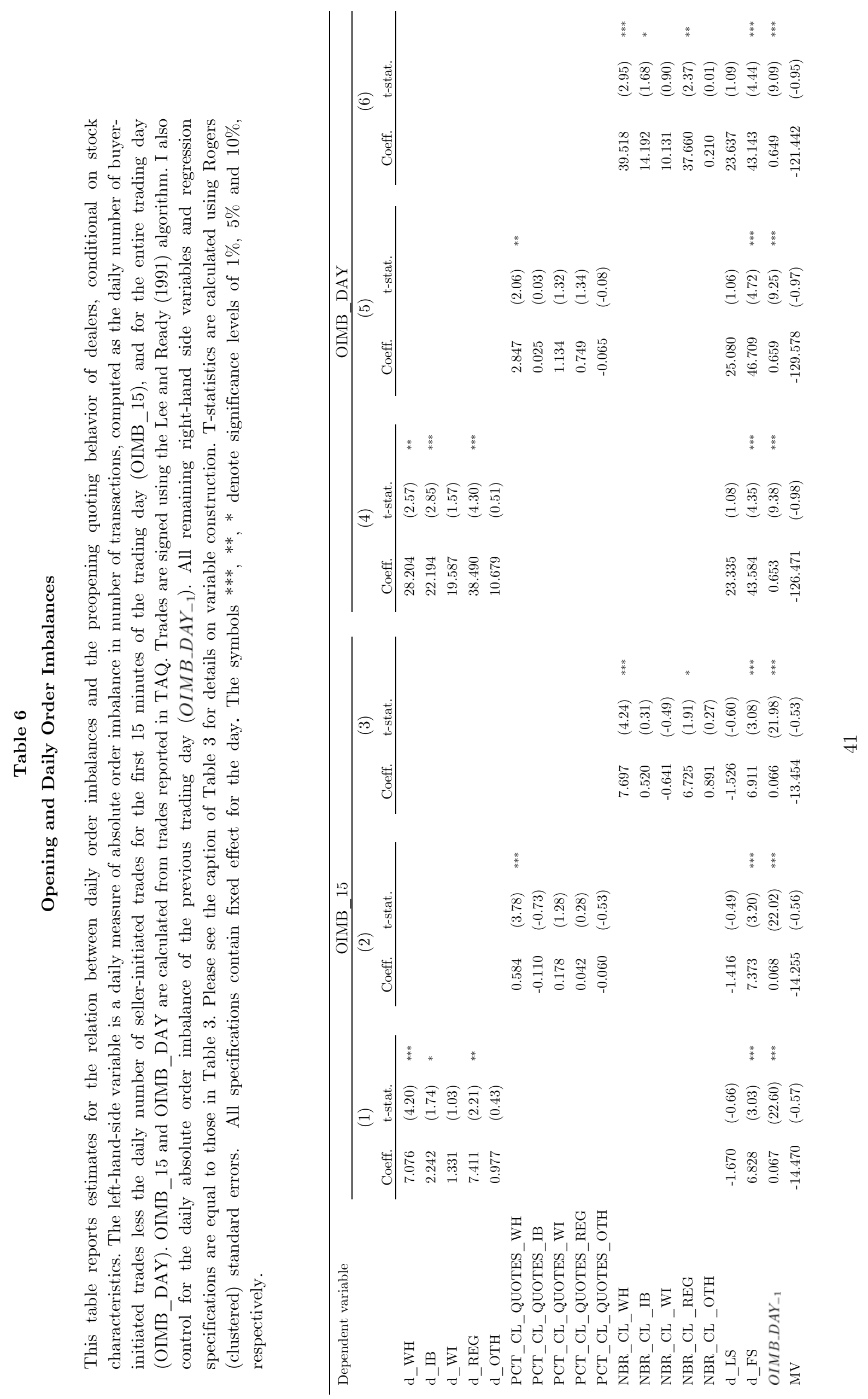


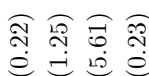

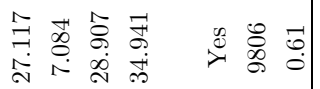

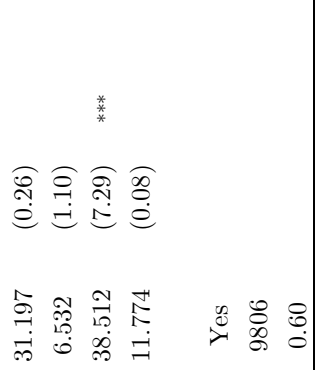

ฝิ

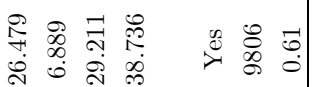

* *

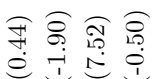

$\stackrel{F}{F}$

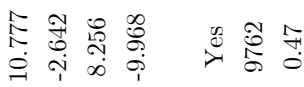

* *

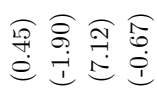

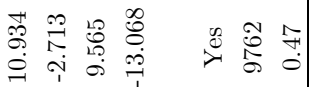

* *

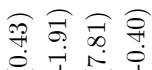

eIN

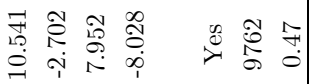

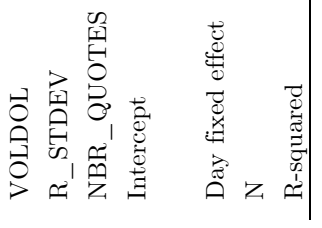


ESSEC Business School Avenue Bernard Hirsch BP 50105

95021 Cergy-Pontoise Cedex

France

Tél. +33(0)134433000

$\mathrm{Fax}+33(0) 134433001$

www.essec.fr

\section{ESSEC Executive Education} CNIT BP 230

92053 Paris-La Défense France

Têl. +33(0)146924900

Fax +33(0)1 46924990

http://formation.essec.fr

ESSEC Business School

Singapore Campus

100 Victoria Street

National Library Building \# 13-02

Singapore 188064

essecasia@essec.fr

Tél. +6568849780

Fax +6568849781

www.essec.edu

Informations

Alison Bougi

+33 (0)134433358

bougi@essec.fr

www.essec.fr

research.center@essec.fr

ISSN 1291-9616 